Portland State University

PDXScholar

\title{
Urban Transportation System Flood Vulnerability Assessment with Special Reference to Low Income and Minority Neighborhoods
}

\author{
Courtney Crosson \\ University of Arizona \\ Daoqin Tong \\ Arizona State University \\ Yinan Zhang \\ University of Arizona
}

Follow this and additional works at: https://pdxscholar.library.pdx.edu/trec_reports

Part of the Transportation Commons, Urban Studies Commons, and the Urban Studies and Planning Commons

Let us know how access to this document benefits you.

\section{Recommended Citation}

Crosson, C., Tong, D., \& Zhang, Y. (2020). Urban Transportation System Flood Vulnerability Assessment with Special Reference to Low Income and Minority Neighborhoods. NITC-SS-1262. Portland, OR:

Transportation Research and Education Center (TREC), 2020. https://dx.doi.org/10.15760/trec.253

This Report is brought to you for free and open access. It has been accepted for inclusion in TREC Final Reports by an authorized administrator of PDXScholar. Please contact us if we can make this document more accessible: pdxscholar@pdx.edu. 


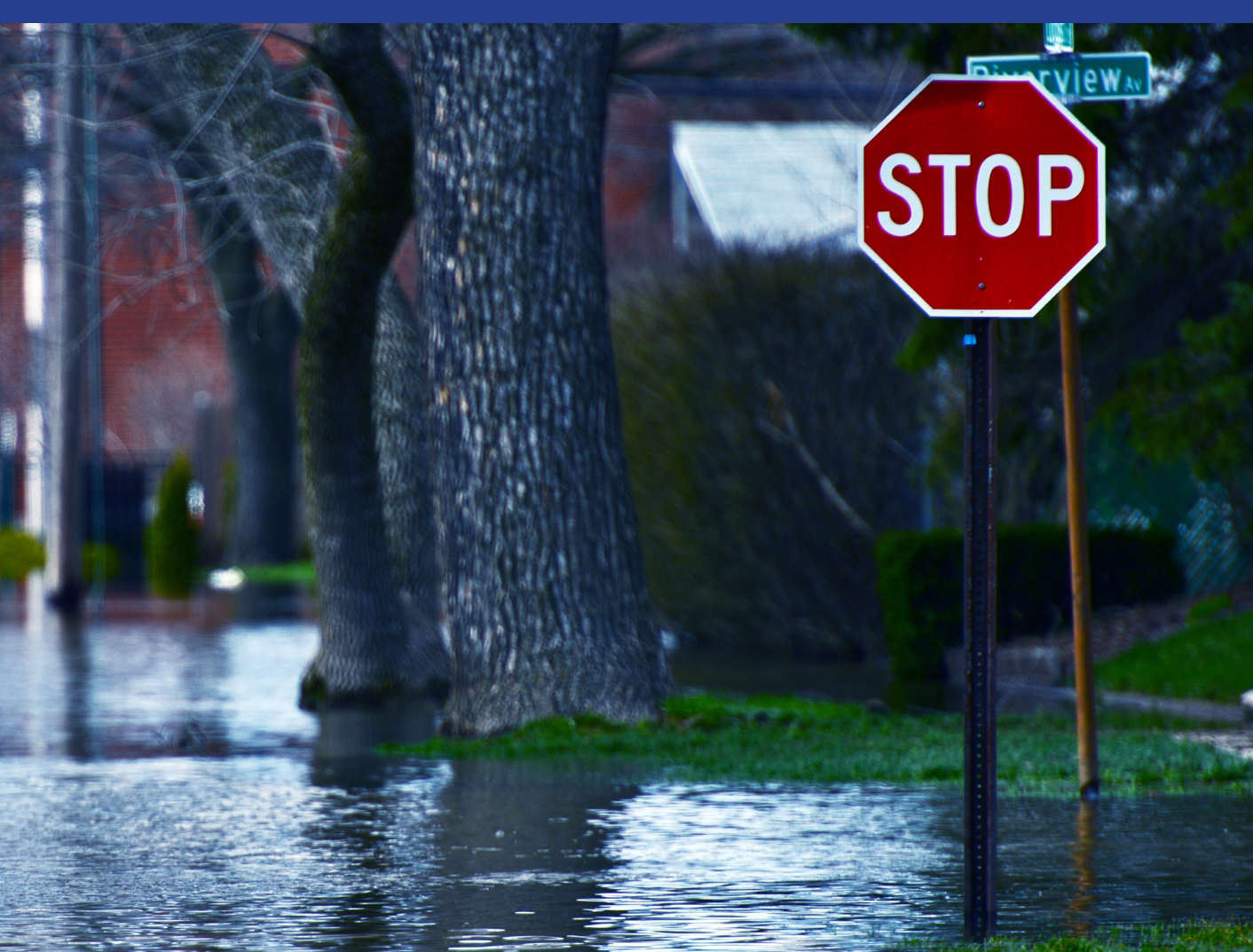

Urban Transportation System Flood Vulnerability Assessment with Special Reference to Low Income and Minority Neighborhoods

\author{
Courtney Crosson, NCARB, LEED AP \\ Daoqin Tong, Ph.D. \\ Yinan Zhang
}

\title{
AR THE UNIVERSITY Al. OF ARIZONA.
}




\title{
Urban Transportation System Flood Vulnerability Assessment with Special Reference to Low Income and Minority Neighborhoods
}

\author{
Final Report \\ NITC-RR-1262 \\ by \\ Courtney Crosson \\ University of Arizona \\ Daoqin Tong \\ Arizona State University \\ Yinan Zhang \\ University of Arizona
}

for

National Institute for Transportation and Communities (NITC)

P.O. Box 751

Portland, OR 97207
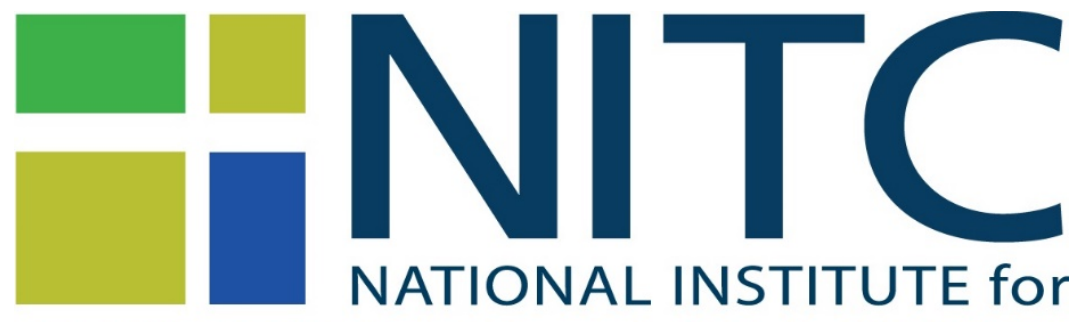

NATIONAL INSTITUTE for

TRANSPORTATION and COMMUNITIES

September 2020 


\begin{tabular}{|c|c|c|c|c|}
\hline \multicolumn{5}{|c|}{ Technical Report Documentation Page } \\
\hline $\begin{array}{l}\text { 1. Report No. } \\
\text { NITC-SS-1262 }\end{array}$ & \multicolumn{2}{|c|}{ 2. Government Accession No. } & \multicolumn{2}{|c|}{ 3. Recipient's Catalog No. } \\
\hline \multirow{2}{*}{\multicolumn{3}{|c|}{$\begin{array}{l}\text { 4. Title and Subtitle } \\
\text { Urban Transportation System Flood Vulnerability Assessment with Special } \\
\text { Reference to Low Income and Minority Neighborhoods }\end{array}$}} & \multicolumn{2}{|c|}{$\begin{array}{l}\text { 5. Report Date } \\
\text { Sept } 2020\end{array}$} \\
\hline & & & \multicolumn{2}{|c|}{ 6. Performing Organization Code } \\
\hline \multicolumn{3}{|c|}{$\begin{array}{l}\text { 7. Author(s) } \\
\text { Courtney Crosson, PI (orcid 0000-0003-1757-8741) } \\
\text { Daoqin Tong (orcid 0000-0001-7005-5128) and Yinan Zhang }\end{array}$} & \multicolumn{2}{|c|}{$\begin{array}{l}\text { 8. Performing Organization Report } \\
\text { No. }\end{array}$} \\
\hline \multirow{2}{*}{\multicolumn{3}{|c|}{$\begin{array}{l}\text { 9. Performing Organization Name and Address } \\
\text { University of Arizona, CAPLA } \\
1040 \text { N Olive Road } \\
\text { Tucson, AZ } 85719\end{array}$}} & \multicolumn{2}{|c|}{ 10. Work Unit No. (TRAIS) } \\
\hline & & & \multicolumn{2}{|c|}{$\begin{array}{l}\text { 11. Contract or Grant No. } \\
1262\end{array}$} \\
\hline \multirow{2}{*}{\multicolumn{3}{|c|}{$\begin{array}{l}\text { 12. Sponsoring Agency Name and Address } \\
\text { National Institute for Transportation and Communities (NITC) } \\
\text { P.O. Box } 751 \\
\text { Portland, Oregon } 97207 \\
\end{array}$}} & \multicolumn{2}{|c|}{$\begin{array}{l}\text { 13. Type of Report and Period } \\
\text { Covered } \\
\text { Final }\end{array}$} \\
\hline & & & \multicolumn{2}{|c|}{ 14. Sponsoring Agency Code } \\
\hline \multicolumn{5}{|c|}{ 15. Supplementary Notes } \\
\hline \multicolumn{5}{|c|}{ 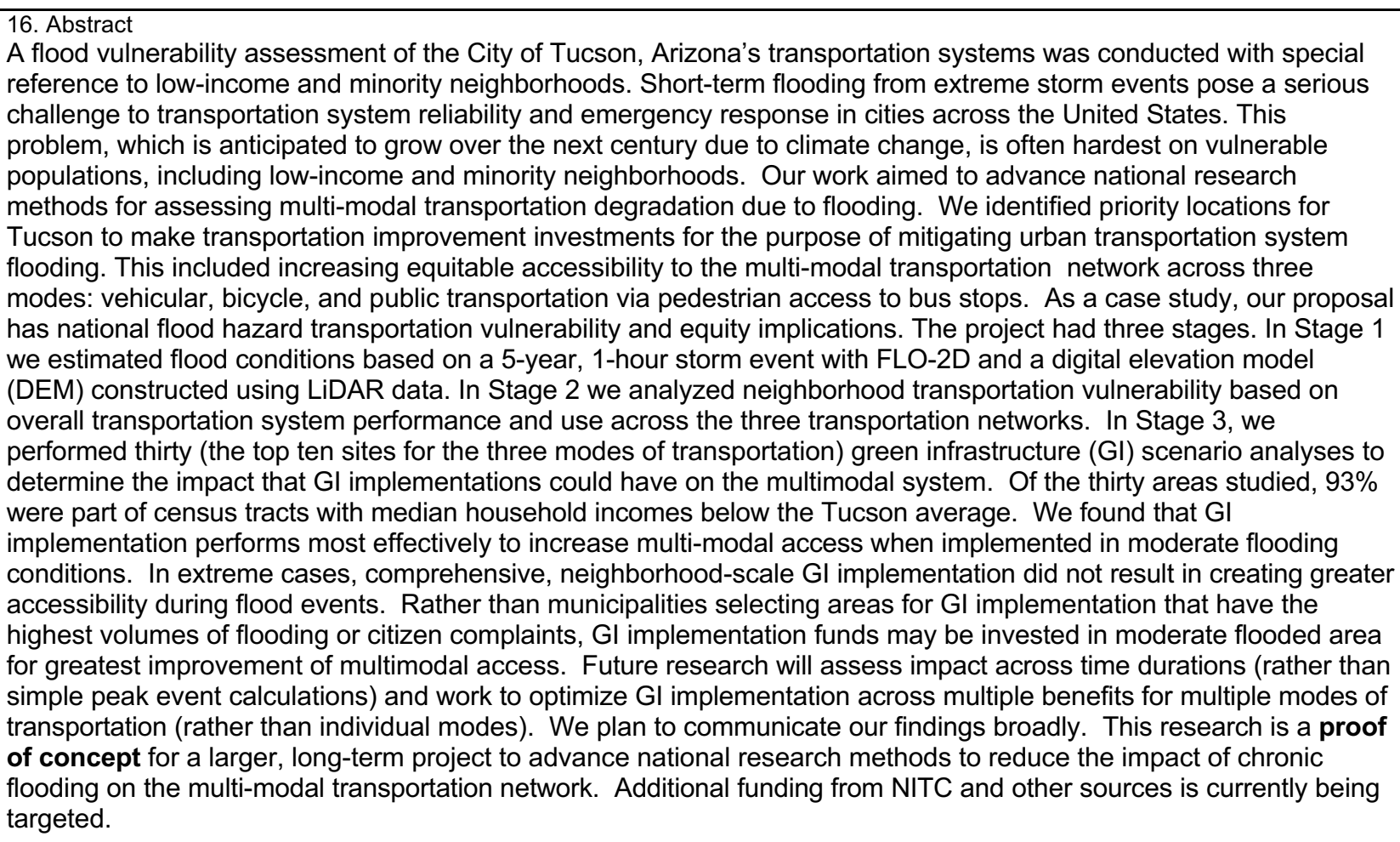 } \\
\hline \multicolumn{2}{|c|}{$\begin{array}{l}\text { 17. Key Words } \\
\text { Green infrastructure, multi-modal network accessibility, mobility and } \\
\text { access, flooding, multi-modal investment }\end{array}$} & \multicolumn{3}{|c|}{$\begin{array}{l}\text { 18. Distribution Statement } \\
\text { No restrictions. Copies available from NITC: } \\
\text { www.nitc-utc.net }\end{array}$} \\
\hline 19. Security Classification (of this report) & $\begin{array}{l}\text { 20. Security Classification } \\
\text { page) } \\
\text { Unclassified }\end{array}$ & & f Pages & 22. Price \\
\hline
\end{tabular}




\section{ACKNOWLEDGEMENTS}

The PI would like to acknowledge partial support from the National Institute for Transportation and Communities (NITC; grant number 1262), a U.S. DOT University Transportation Center and cash and in-kind support from Pima County Flood Control District and the City of Tucson Water Department. Further, this work was carried out through the support of Yinan Zhang, PhD student in the School of Geography and Development, University of Arizona.

\section{DISCLAIMER}

The contents of this report reflect the views of the authors, who are solely responsible for the facts and the accuracy of the material and information presented herein. This document is disseminated under the sponsorship of the U.S. Department of Transportation University Transportation Centers Program in the interest of information exchange. The U.S. Government assumes no liability for the contents or use thereof. The contents do not necessarily reflect the official views of the U.S. Government. This report does not constitute a standard, specification, or regulation. 


\section{TABLE OF CONTENTS}

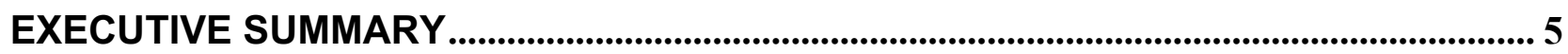

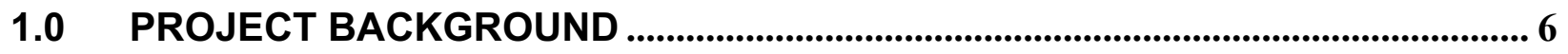

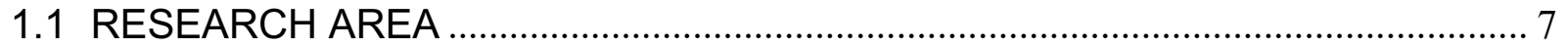

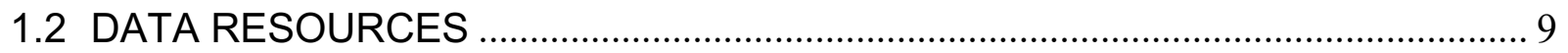

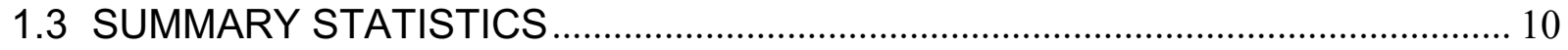

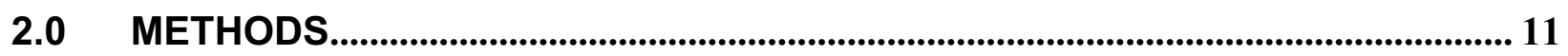

2.1 STAGE 1: REGIONAL FLOOD ASSESSMENT ………................................. 14

2.2 STAGE 2: MULTIMODAL NETWORK TRANSPORTATION VULNERABILITY

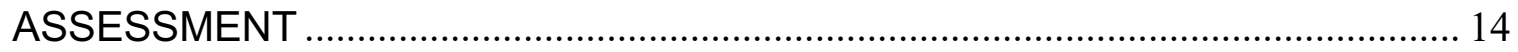

2.2.1 Research Areas and Low Income Neighborhood Statistics .......................... 17

2.3 STAGE 3: INTEGRATED HYDROLOGIC-TRANSPORTATION SIMULATIONS FOR THIRTY GI SCENARIOS …………………........................................... 19

2.3.1 Research Area Delineation............................................................................... 19

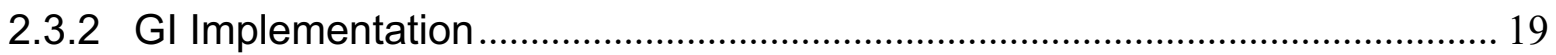

2.4 STAGE 4: IMPACT ASSESSMENT WITH RESULTING DESIGN PRIORITIES 22

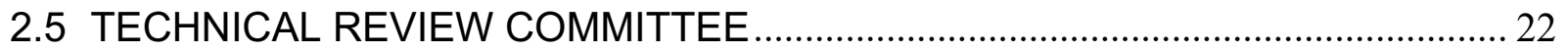

3.0 RESULTS: THIRTY PRIORITY SITES AND SEGMENTS ...................................24

3.1 VEHICULAR TRAFFIC: TEN CAR PRIORITY SITES AND SEGMENTS ............. 24

3.2 BICYCLE FLOWS: TEN BICYCLE PRIORITY SITES AND SEGMENTS ............ 27

3.3 PEDESTRIAN ACCESS TO BUS STOPS: TEN PEDESTRIAN PRIORITY SITES

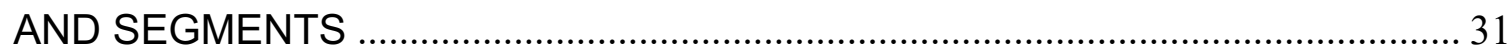

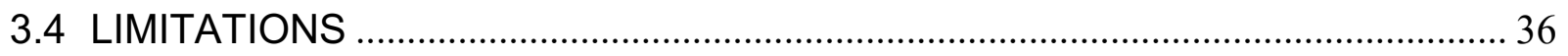

4.0 PRELIMINARY CONCLUSIONS ...................................................................... 37

4.1 MAXIMIZING GI INVESTMENT TO IMPROVE MULTIMODAL MOBILITY AND

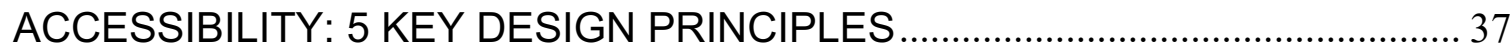

4.1.1 Principle 1: Prioritize Upstream Mitigation …………………................................. 37

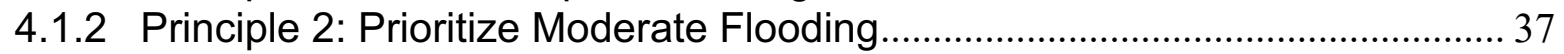

4.1.3 Principle 3: Prioritize Network Gains ................................................................... 38

4.1.4 Principle 4: Prioritize Large Right-of-Way Areas............................................. 38

4.1.5 Principle 5: Prioritize Pedestrian Travel Locations .......................................... 38

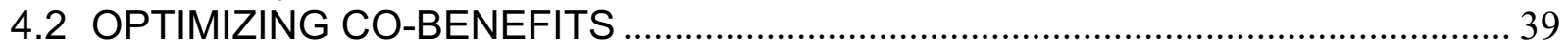

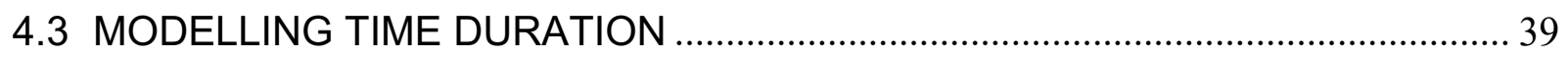

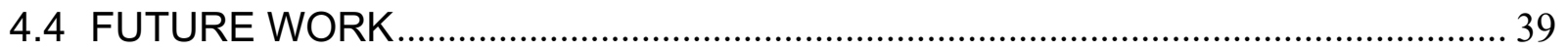

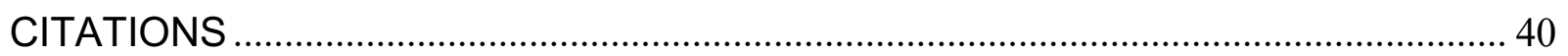

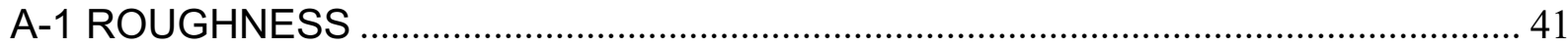

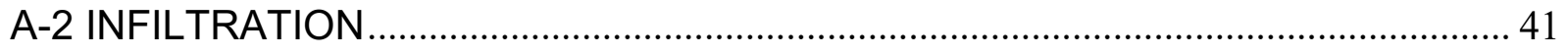

APPENDICES

APPENDIX A: Coefficient Tables 


\section{LIST OF TABLES}

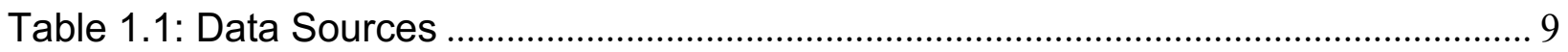

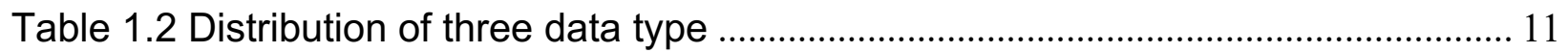

Table 2.1 Overall water depth From Stage 1................................................................. 14

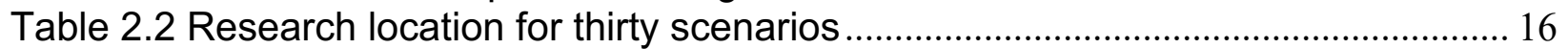

Table 2.3 Flow chart of research location selection ..................................................... 17

Table 2.4 Traffic scenario \#2 - Research area (left) ........................................................ 21

Table $2.5 \mathrm{Gl}$ implementation (right).................................................................................. 21

Table 2.6 Bicycle scenario \#7 - Research area (left) ………............................................ 21

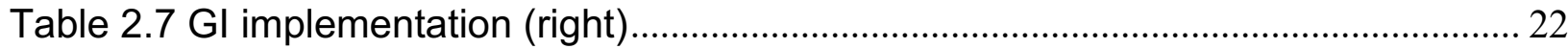

Table 2.8 Pedestrian Scenario \#10 - Research area (left) ............................................. 22

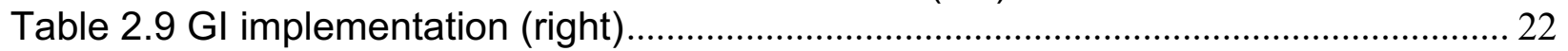

Table 3.1 Results evaluation .................................................................................. 25

Table 3.2 Water depth comparison for bicycle scenario \#7 before (left) and after (right)

$\mathrm{Gl}$. 28

\section{LIST OF FIGURES}

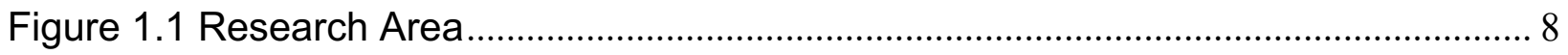

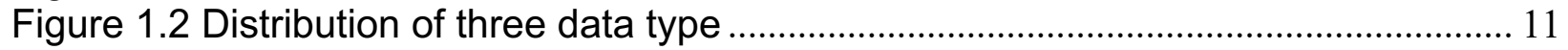

Figure 2.1 The project completed four research stages ................................................... 13

Figure 2.2 Overall water depth From Stage 1 ……........................................................ 14

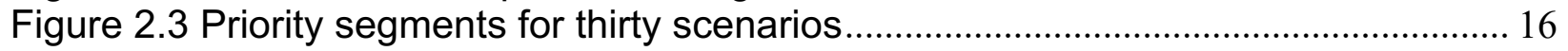

Figure 2.4 Flow chart of priority segments and sites selection ..................................... 17

Figure 2.5 Typical roadside basin Gi implementation foe each mode of transportation. 20

Figure 2.6 Traffic scenario \#2 - Priority site and segment (left) ........................................ 21

Figure $2.7 \mathrm{Gl}$ implementation across the priority site(right) ............................................. 21

Figure 2.8 Bicycle scenario \#7 - Priority site and segment (left) ……………………...... 21

Figure $2.9 \mathrm{Gl}$ implementation across the priority site (right) …………............................ 22

Figure 2.10 Pedestrian Scenario \#10 - Priority site and segment (left)............................. 22

Figure $2.11 \mathrm{Gl}$ implementation across the priority site (right) ........................................... 22

Figure 3.1 Results evaluation........................................................................................... 25

Figure 3.2 Water depth comparison for bicycle scenario \#7 before (left) and after (right)

GI.

28 


\section{EXECUTIVE SUMMARY}

A flood vulnerability assessment of the City of Tucson, Arizona's multi-modal transportation system was conducted with special reference to low-income and minority neighborhoods. Short-term flooding from extreme storm events pose a serious challenge to transportation system reliability and emergency response in cities across the United States. This problem, which is anticipated to grow over the next century due to climate change, is often hardest on vulnerable populations, including low-income and minority neighborhoods. Our work aimed to advance national research methods for assessing multi-modal transportation degradation due to flooding. We identified priority locations for Tucson to make transportation improvement investments for the purpose of mitigating urban transportation system flooding. This included increasing equitable accessibility to the multi-modal transportation network across three modes: vehicular, bicycle, and public transportation via pedestrian access to bus stops. As a case study, our proposal has national flood hazard transportation vulnerability and equity implications.

The project had three stages. In Stage 1 we estimated flood conditions based on a 5year, 1-hour storm event with FLO-2D and a digital elevation model (DEM) constructed using LiDAR data. This hydrological analysis was performed at the city-scale and a 20foot grid resolution. In Stage 2 we analyzed neighborhood transportation vulnerability based on overall transportation system performance and use across the three transportation networks. Data from the most recent 10-years of vehicular counts, bicycle counts, and bus stop ridership were used to identify the top ten priority locations for flood mitigation based on usage of each of the three modes. In Stage 3, we preformed thirty green infrastructure (GI) scenario analyses in these selected Stage 2 priority locations to determine the impact of neighborhood-scale $\mathrm{Gl}$ implementations in the right-of-way. Of the thirty areas studied, $93 \%$ were part of census tracts with median household incomes below the Tucson average. The hydrological analysis was performed at a neighborhood-scale for these sites and at a 5-foot grid resolution. Adequate access to the transportation network during the modelled event was defined as peak flood depths below an accessibility threshold for each of the three modes (for vehicles $=1$ foot, for bicycles $=0.25$ feet of pedal height, and for pedestrians $=0.25$ feet).

This report starts with an outline of the project background. Then the three stage methodology is described. Results across the thirty modelled scenarios are discussed. Preliminary conclusions complete the report. Across the thirty scenarios, we found that comprehensive neighborhood-scale GI implementation in the right-of-way is most effective at increasing multi-modal access when implemented in moderate flooding conditions. In extreme flooding cases, comprehensive Gl implementation in the right-ofway did not result in greater accessibility during flood events. Rather than municipalities selecting areas for $\mathrm{Gl}$ implementation that have the highest volumes of flooding or 
citizen complaints, GI implementation funds may be invested in moderate flooded area for greatest improvement of multimodal access. Future research will assess impact across time durations (rather than simple peak event calculations) and work to optimize GI implementation across multiple benefits for multiple modes of transportation (rather than individual modes). We plan to communicate our findings broadly, starting with summer presentations to City and County leadership and staff. This research is a proof of concept for a larger, long-term project to advance national research methods to reduce the impact of chronic flooding on the multi-modal transportation network, particularly using strategic $\mathrm{Gl}$ implementation.

\subsection{PROJECT BACKGROUND}

Short-term flooding from extreme storm events pose a serious challenge to transportation system reliability and emergency response in cities across the United States. This problem, which is anticipated to grow over the next century due to climate change, is often hardest on vulnerable populations, including low-income and minority neighborhoods. The Special Report on Climate Change by the Transportation Research Board states, "Potentially, the greatest impact of climate change for North America's transportation systems will be flooding (National Research Council, 2008)." In 2016 alone, the United States suffered estimated property damages of \$15 billion dollars and 83 deaths from flash floods - comprising over half of all damages caused by natural disasters in the United States and the highest death rate. Over $80 \%$ of deaths from extreme storms are transportation related. The fourth National Climate Assessment warns of increases in the intensity and duration of precipitation events in the coming decades, leading to a greater severity and frequency of flash floods in portions of the United States (Wuebbles et al., 2017). This concern is exacerbated by a national trend in deteriorating stormwater infrastructure and increased urbanization with densification of impervious land cover. In coastal cities with accelerated development, surge events overwhelm infrastructure that was not expanded with changes in land cover. In older cities with combined sewer systems, floods result in outflows of raw sewage into ecological zones. In sprawling cities with extreme seasonal storms, a historic failure to invest in infrastructure during periods of growth causes significant, annual property damage. The damages will worsen with the projected increases in extreme precipitation if innovations are not made. However, municipalities also face resource constraints. Under limited budgets governments increasingly are asked to monitor, prevent, and respond to the impacts of climate change.

Green Infrastructure $(\mathrm{Gl})$ is a growing urban trend where stormwater is managed by expanding pervious areas of natural vegetation throughout a city. The Environmental Protection Agency defines $\mathrm{Gl}$ as "an approach to water management that protects, restores, or mimics the natural water cycle and one which is effective, economical, and enhances community safety and quality of life (EPA 2020)." This project aimed to assess the impact of Green Infrastructure (GI) installations on the multi-modal transportation system (vehicle, bicycle, and pedestrian access to bus stops) to support 
a systematic prioritization of these GI projects in the right-of-way toward increased transportation network accessibility and expanded equity.

\subsection{RESEARCH AREA}

The City of Tucson sits within the United States Southwest where studies have projected a more arid climate and higher risk of water shortages over the coming century (Ault et. al, 2016). While water resources become scarce, population in the region has grown considerably in the past decades and the growth is expected to continue. In Arizona, the population is anticipated to increase by $25 \%$ between the years 2012 and 2030 .

Located in the Sonoran Desert, Tucson experiences climate extremes with multiyear drought, seasonal dryness, and the annual North American Monsoon season. Tucson is subject to fluctuations in daily volumes and seasonal patterns of rainfall. Tucson has a light (roughly December through February) and heavy (roughly July through September) rainy season joined by intense stretches of heat and dryness. The City of Tucson, Arizona is well suited for the research given its socioeconomic and climate extremes, which present flooding and equity challenges. Tucson has a population of approximately 527,586 residents (US Census Bureau, 2016). In 2018, the poverty rate of the Tucson MSA was $17.8 \%$, which was the second poorest among the twelve Western US MSAs. Residents are socially and economically diverse. Wide gaps are found in income and educational attainment. The research area for the first stages is the City of Tucson, which covers 22 washes along the Santa Cruz and Rillito Rivers. In the final stage of analysis, priority locations at a neighborhood scale were identified throughout the City for $\mathrm{Gl}$ implementation and finer resolution modelling.

Tucson has a unique stormwater management history. The majority of the urban center of Tucson does not currently have storm water piping. Streets were designed to carry the heavy rain flows that occur during the winter and monsoon seasons to washes throughout the city. Over time, the city grew and greatly shifted its majority pervious land cover to impervious. This currently results in annual flooding in parts of the city leading to chronic property damage and loss in transportation accessibility. Tucson has the highest yearly extreme storm count across Western US Metropolitan Statistical Areas (MSAs) (Bakkensen and Johnson, 2017). These urban water extremes affect citizens directly and disproportionately. Tucson averages $\$ 9.5$ million in property losses each year from flooding in the city center where stormwater infrastructure was historically not installed, predominately in lower income areas (Bakkensen and Johnson, 2017).

To address these issues, the County and City are working to collaboratively develop and optimize a network of sites that will address current flooding issues and retrofit Tucson with a new, softer, greener infrastructure. The City of Tucson established a Green Streets policy in 2013 which requires that the department of transportation design new upgraded streets that convey stormwater into GI features. Additionally, a goal of covering streets with a $25 \%$ tree canopy is stated. In 2019 , the City passed a Complete Streets policy with the goal of ensuring safety and accessibility to the 
transportation network to a diversity of citizens. In spring 2020, the Tucson City Commissioners adopted a new GSI fee, previously absent from community water bills. In contrast to the two existing fees for potable water and sewer, this third fee funds the planning and construction of a decentralized GI system throughout the city. The goal of using Gl in Tucson is to reduce areas of localized flooding and improve co-benefits such as increased shade, reduced heat island effect, and decreased nonpoint source pollution throughout the city. GI has been shown to be more cost effective than grey stormwater infrastructure (Jaffe 2011) and have multiple benefits beyond flood reduction (Tzoulas et al., 2007). These three recent policies support the implementation of efficient and connected transportation and stormwater networks. However, criteria for the selection of projects for the GSI fee investments are not yet clear. This research project sought to produce a set of criteria to prioritize implementations for maximum impact across multiple scales and modes.

The research area for Stage 1 and 2 is the City of Tucson, which covers 22 washes along Santa Cruz River and Rillito River. This research area is illustrated in Figure 1.1 within the red lines. In Stage 3, priority locations at a neighborhood-scale were identified for closer modeling throughout this broader research area.

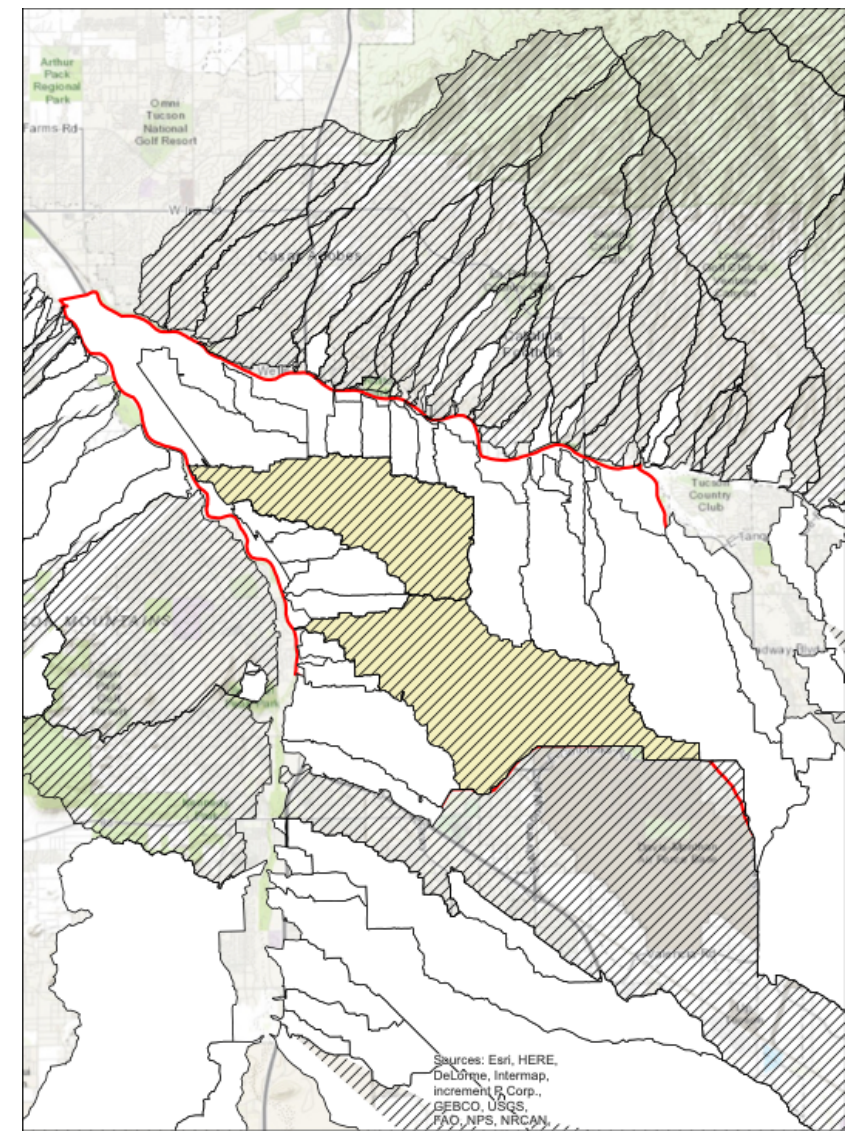

Figure 1.1 Research Area 


\subsection{DATA RESOURCES}

Data for the analyses undertaken during Stage 1,2, and 3 were provided by various governmental agencies including Tucson Department of Transportation, Pima County Geographic Information System, Arizona Department of Transportation, Pima Association of Governments (the regional transportation authority), and U.S. Geological Survey. Table 1.1 provides a summary of these data sources, types, and a description of their use in our research.

Table 1.1: Data Sources

\begin{tabular}{|c|c|c|c|}
\hline Data Name & Source & Data Type & Description \\
\hline $\begin{array}{l}2018 \text { Land- } \\
\text { Use-Land- } \\
\text { Cover Image }\end{array}$ & PIMA GIS & Raster & $\begin{array}{l}\text { The land cover data generated by remote sensing } \\
\text { classification based on } 2015 \text { orthoimagery. The } \\
\text { land cover type includes water, trees/shrubs, } \\
\text { irrigated land, desert, barren/ bedrock, impervious, } \\
\text { structures, and road. The land cover data were } \\
\text { used to generate the manning's n and infiltration } \\
\text { data input in Flo-2D. }\end{array}$ \\
\hline DEM & USGS & Raster & $\begin{array}{l}\text { DEM data provide terrain input in Flo-2D with a } \\
\text { resolution of } 2 \text { feet. }\end{array}$ \\
\hline $\begin{array}{l}\text { Road } \\
\text { Segments }\end{array}$ & TDOT & Shapefile & $\begin{array}{l}\text { The major roads in Tucson where traffic flow were } \\
\text { collected, which were used to select and evaluate } \\
\text { the flood mitigating effects of GI on transportation. }\end{array}$ \\
\hline Street & PIMA GIS & Shapefile & $\begin{array}{l}\text { All the streets in Tucson including major and minor } \\
\text { roads, which were assumed as all the walkable } \\
\text { streets for the pedestrian. The data were used to } \\
\text { select prior locations in the pedestrian scenario. }\end{array}$ \\
\hline $\begin{array}{l}\text { Bicycle } \\
\text { Route }\end{array}$ & PIMA GIS & Shapefile & $\begin{array}{l}\text { Bicycle route in the city of Tucson, which were } \\
\text { used to select prior locations and evaluate the } \\
\text { flood mitigating effects of GI in bicycle flow } \\
\text { scenario. }\end{array}$ \\
\hline Intersection & PIMA GIS & Shapefile & $\begin{array}{l}\text { The intersection points of street network where } \\
\text { bicycle flow were collected with orientations. }\end{array}$ \\
\hline Bus Stop & PIMA GIS & Shapefile & $\begin{array}{l}\text { The point of bus stops where ridership were } \\
\text { collected. }\end{array}$ \\
\hline $\begin{array}{l}\text { Parcel } \\
\text { Region }\end{array}$ & PIMA GIS & Shapefile & The polygons of parcel region. \\
\hline $\begin{array}{l}\text { Daily Traffic } \\
\text { by Road } \\
\text { Segment }\end{array}$ & $\begin{array}{l}\text { PAG; } \\
\text { ADOT }\end{array}$ & Excel & $\begin{array}{l}\text { Hourly traffic ranging from } 1998 \text { to } 2017 \text {. The } \\
\text { latest record of traffic of each road segments were } \\
\text { selected to calculate the daily traffic. ADOT data } \\
\text { were used as supplement where PAG data were } \\
\text { not available. }\end{array}$ \\
\hline
\end{tabular}




\begin{tabular}{l|l|l|l}
$\begin{array}{l}\text { Daily Bicycle } \\
\text { Flow by } \\
\text { Intersection }\end{array}$ & TDOT & Excel & $\begin{array}{l}\text { Daily bicycle flow at intersections with four } \\
\text { orientations ranging from } 2013 \text { to } 2018 .\end{array}$ \\
\hline $\begin{array}{l}\text { Bus Stop } \\
\text { Ridership }\end{array}$ & TDOT & Excel & Daily ridership at bus stops with people on\&off. \\
\hline
\end{tabular}

\subsection{SUMMARY STATISTICS}

The data resources were cleaned and organized for use in this project. Table 1.2 and Figure 1.2 display the basic information and distribution used in Stage 2 to estimate transportation system vulnerability based on peak flood depth during a 5-year, 1-hour rain event. Stage 3 used the top ten areas of vulnerability of the three scenarios vehicular traffic, bicycle flow, and ridership at bus stops. The road segments with highest traffic are interstate highways, which were excluded from candidate research locations. The intersections with bicycle flow are shown as orange points and mainly concentrated around campus. Bus stops are concentrated along Alvernon Way and the Ronstadt Center.

Table 1.2 Summary Statistic of the three transportation networks

\begin{tabular}{l|l|l|l}
\hline & Traffic & Bicycle Flow & Bus Stop \\
\hline Count: & 980 & 236 & 1119 \\
\hline Minimum: & 87 & 1 & 0 \\
\hline Maximum: & 163606 & 818 & 2860 \\
\hline Sum: & 20578273 & 15585 & 124531 \\
\hline Mean: & 20998.24 & 66.04 & 111.29 \\
\hline Standard Deviation: & 19884.52 & 114.64 & 210.98 \\
\hline
\end{tabular}




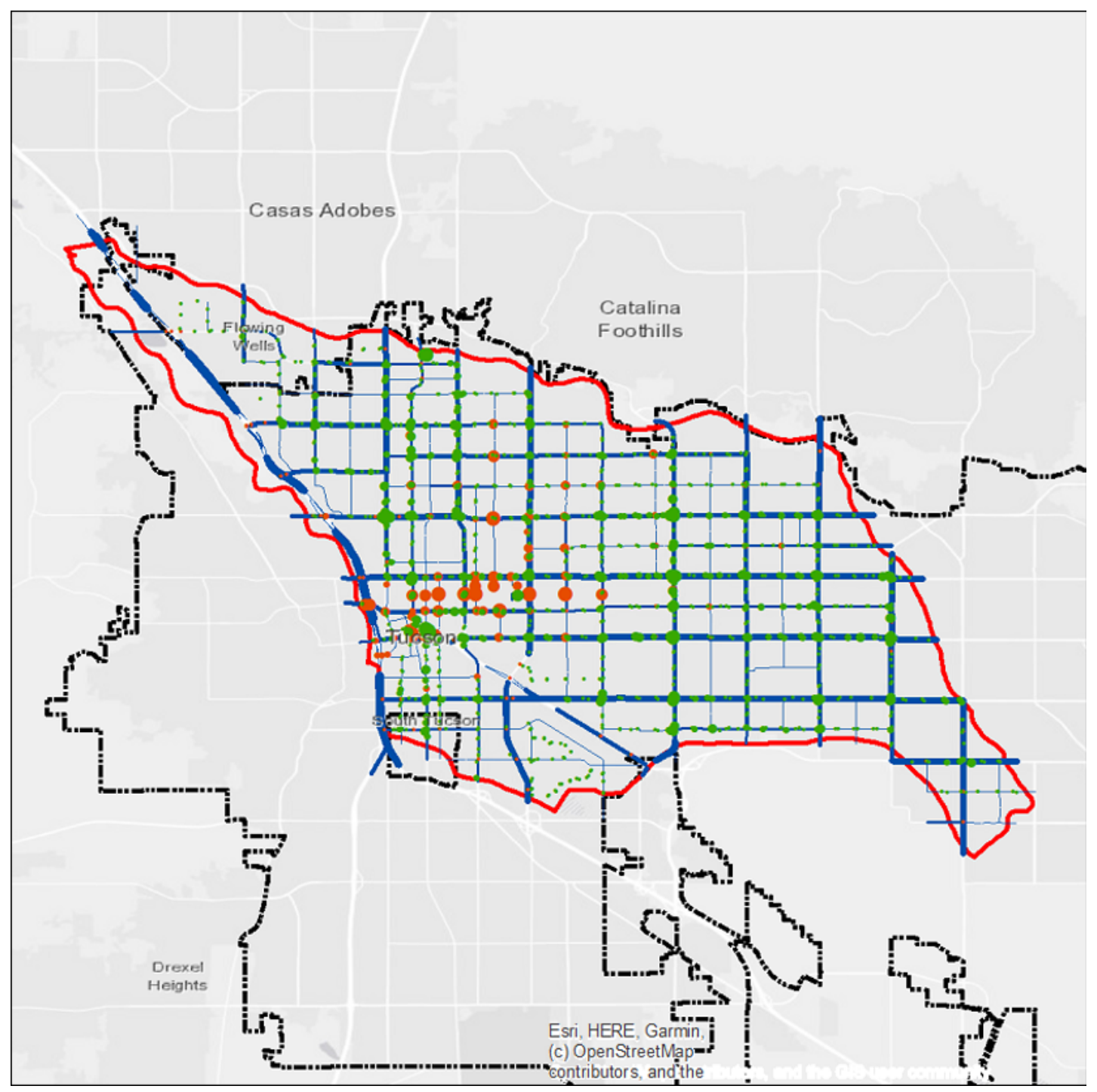

Figure 1.2 Distribution of three data type

\subsection{METHODS}

This project used a multiscalar and multimodal framework to predict impacts of GSI implementation on accessibility to the multimodal transportation system. This section outlines the novel modeling approach comprised of four stages (Figure 2.1).

- Stage 1, Regional Flood Assessment: Regional flood conditions were estimated based on a 1-hour, 5-year rain event at a 20 -foot resolution across the City's 
transportation system using digital elevation model (DEM) data. This first stage established the baseline for later stages of analysis.

- Stage 2, Multimodal Transportation Network Vulnerability Assessment: Vehicular traffic counts, bicycle counts, and bus stop ridership data were used to identify the top accessed locations across the transportation system. These locations were then catalogued by the flooding modelled in Stage 1 to identify the top ten research areas. Thirty total research locations were selected - ten for each of the three modes of transportation.

- Stage 3, Integrated Hydrological-Transportation Simulations: Comprehensive GI installations were implemented at the neighborhood basin scale for all thirty research locations. GI roadside basins were implemented at 9-inch depths in all available right-of-way and modelled at a finer scale, 5 -foot grid resolution, for a 1hour, 5-year event to obtain detail flooding conditions in these locations.

- Stage 4, Impact Assessment: Impact assessments were completed across the three modes of transit and two scales of analysis resulting in five key design performance priorities.

Data for the analyses undertaken during Stage 1, 2, and 3 were provided by various governmental agencies including Tucson Department of Transportation (TDOT), Pima County Geographic Information System (GIS), Arizona Department of Transportation (ADOT), Pima Association of Governments (PAG, the regional transportation authority), and U.S. Geological Survey (USGS). To complete the hydrological modeling used in Stage 1,2, and 3, digital elevation model data from USGS provided terrain input in Flo2D, a common hydrological modeling program. County GIS also provided land cover data generated by remote sensing classification based on 2015 orthoimagery. The land cover types include water, trees/shrubs, irrigated land, desert, barren/ bedrock, impervious, structures, and road. The land cover data were used to generate the manning coefficients and infiltration data input for Flo-2D. Hydraulic structures from County records and major transit infrastructures (such as bridges and underpasses) from City and County records were incorporated in the all stages of the modelling work.

For transportation network analyses in Stage 2 and 3, shape files of the street network, bicycle routes, and bus stop locations were acquired from Pima County GIS. For vehicle traffic by road segment, hourly traffic ranging from 2006 to 2017 was used. The latest record of traffic of each road segments were selected to calculate the daily traffic. ADOT data were used for state owned property as supplement when PAG data were not available. For bicycle counts data, daily bicycle flow at sampled intersections from 
2013 to 2018 with four orientations was used. Daily ridership at bus stops of on and off counts from 2008 were used for pedestrian access to the public bus system.

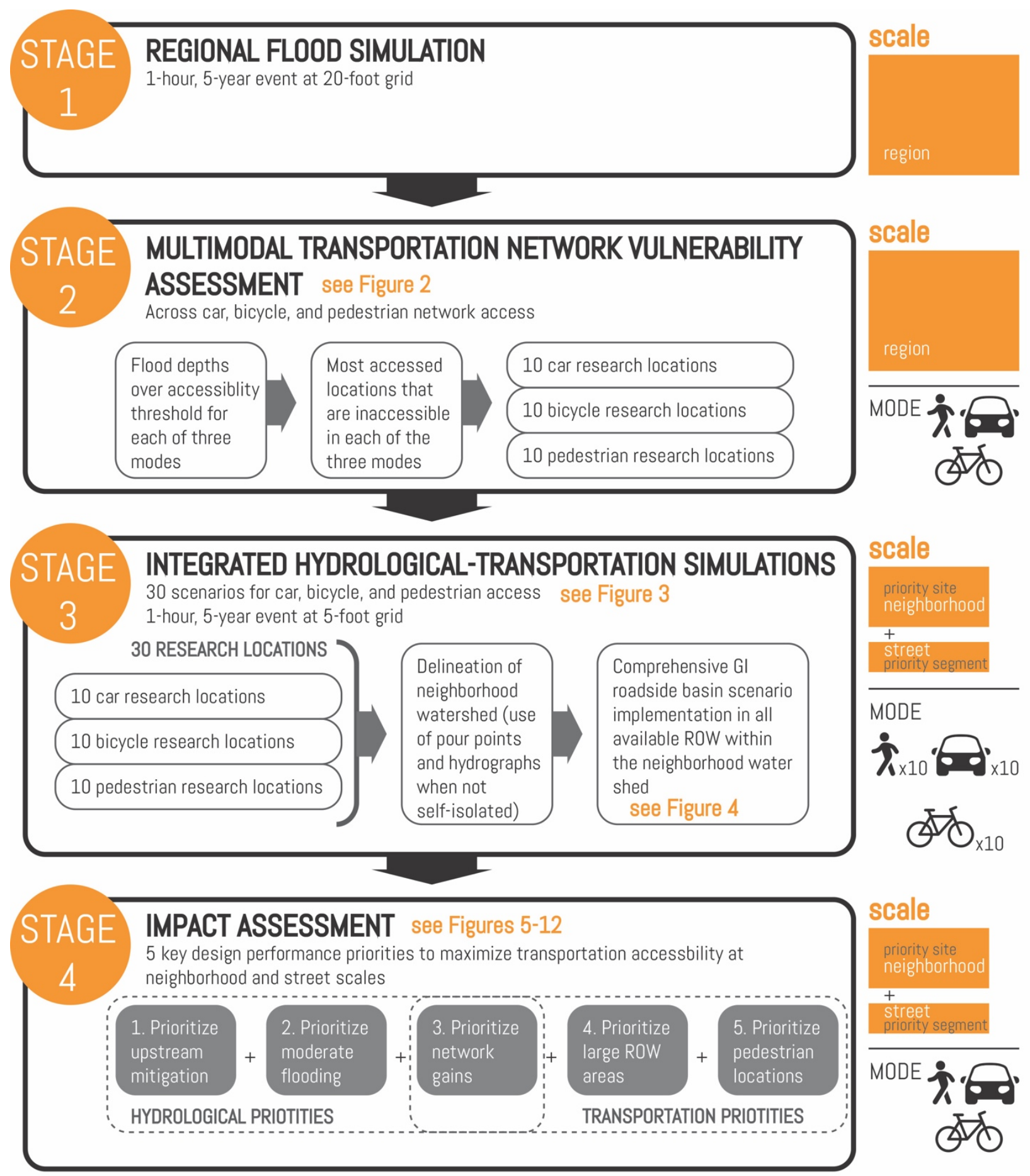

Figure 2.1 The project completed four research stages 


\subsection{STAGE 1: REGIONAL FLOOD ASSESSMENT}

The objective of the first stage was to complete a comprehensive regional flood assessment to identify the locations of highest peak flooding levels across the transportation network. These results were used as inputs for the research area scenario selection for Stage 2 and 3. This regional flood assessment was conducted at the County specified design criteria of a 1-hour, 5-year event at a 20-foot resolution. FLO-2D, a common hydrologic and hydraulic modeling software for high-resolution urban flooding simulation, was used to complete the analysis. The inputs for the model included elevation (from digital elevation model), infiltration and roughness (generated from land cover data from County LiDAR and orthophoto), hydraulic structures (from County Flood Control records), and major transit infrastructure such as bridges and underpasses (from City and County records). When there was a bridge and an underpass, the results for the underpass where given priority in FLO-2D output results. When there was a bridge and a non-road feature, the bridge was given priority in FLO2D output results. The detailed values for infiltration and roughness are in Appendix A.

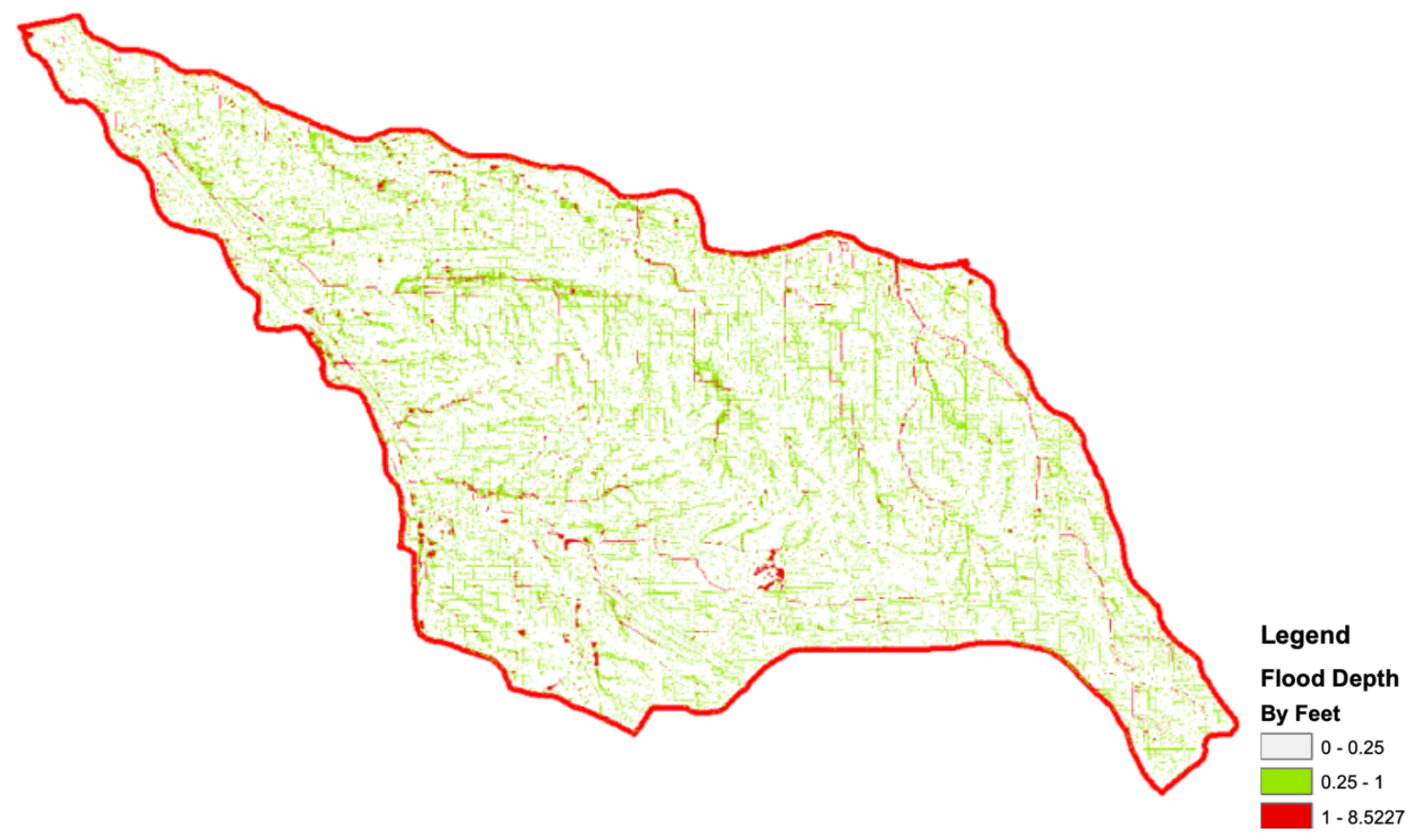

Figure 2.2 Overall water depth From Stage 1

\subsection{STAGE 2: MULTIMODAL NETWORK TRANSPORTATION VULNERABILITY ASSESSMENT}

The objective of Stage 2 was to select the thirty priority research locations by completing a multimodal network vulnerability assessment. These thirty locations were comprised of ten locations for each of three modes of transportation: car, bicycle, and pedestrian access to bus stops. The modeling results from Stage 1 were overlaid with data for vehicular traffic counts and flow, bicycle counts and flow, and ridership at bus 
stop (on and off) to complete the vulnerability assessment. Figure 2.2 displays the results from Stage 2, the top ten most accessed locations identified for each of the three modes of transportation. The main process of selecting a research location is shown in the flow chart in Figure 2.4.

To complete the vulnerability assessment, thresholds of access during rain events were set for each of the three modes. For cars, a flood depth of above 1-foot was set as the threshold of inaccessibility in the modeled 1-hour rainfall event with a 5-year return period. For bicycles and pedestrians, flood depths above 0.25 feet were the threshold of inaccessibility.

There were several specific flooding cases for each mode of transportation that were excluded in the vulnerability assessment. First, for cars, a threshold of less than 20 feet (approximately a car length) was specified as the criterion for exclusion. The other three criteria applied to exclude a road segment as a potential research location were: the road segment was an interstate highway; the road segment was outside the boundary of the research area; and the road segment was an underpass. In the ten bicycle scenarios, segments that were flooded less than five feet (approximately a bicycle length) were excluded. The top ten intersections with highest bicycle flow that connected with the flooded segments were selected and considered as research locations. In the ten pedestrian scenarios, all the streets that intersected with impassable areas were considered as flooded segments, and thus the bus stops connected to the flooded segments were assumed to be inaccessible to the pedestrian.

For cars, the ten flooded road segments with the highest traffic are shown as blue lines in Figure 2.3, labeled by the name of the street. The top ten points are shown as red points in Figure 2.3, labeled with the total bicycle flow to four orientations. The majority of these research areas are concentrated around the University of Arizona campus. The top ten stops with highest ridership were chosen as research locations in this scenario, shown as green points and labeled with the total ridership) in Figure 2.3. 


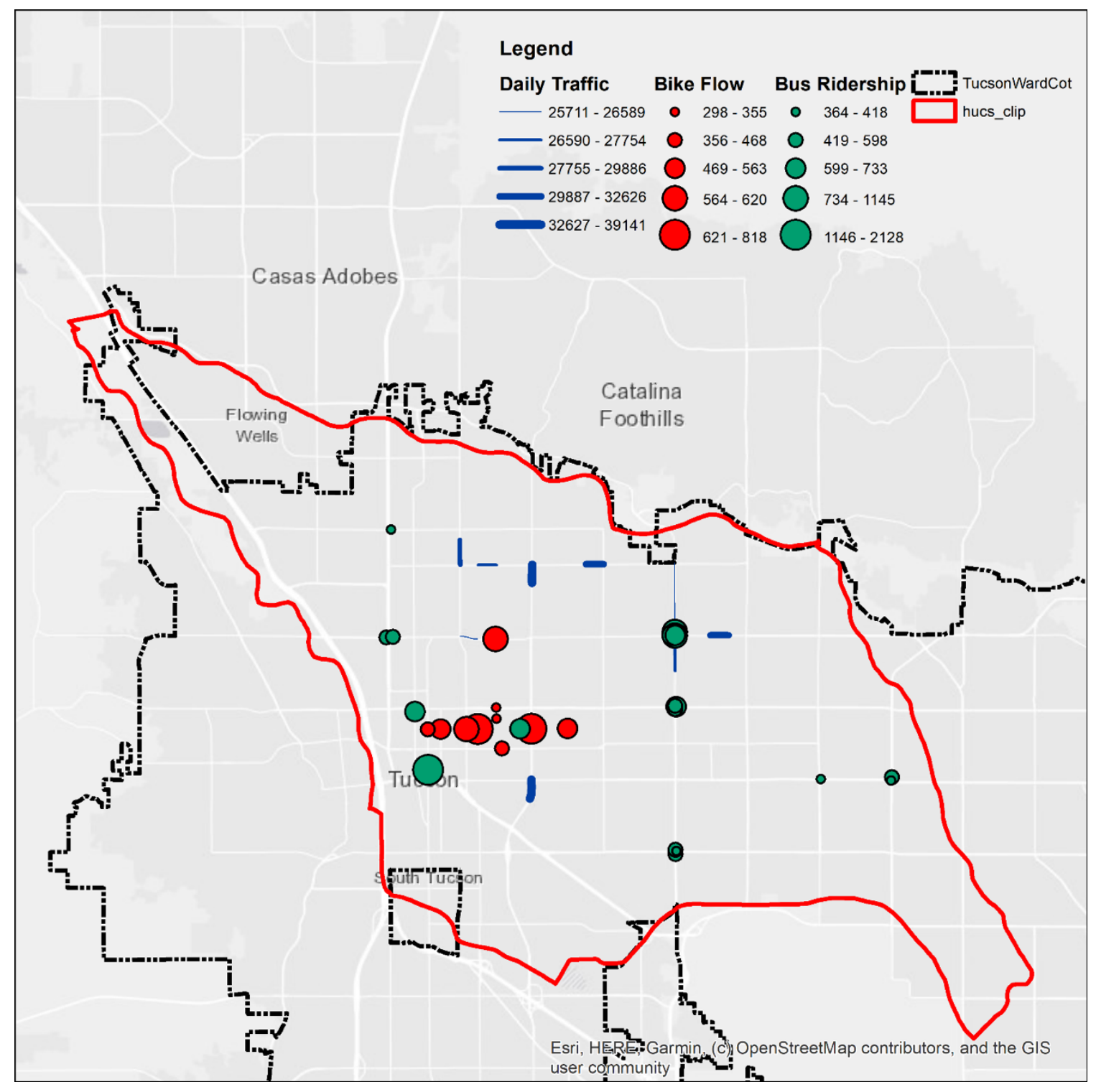

Figure 2.3 Priority segments for thirty scenarios 


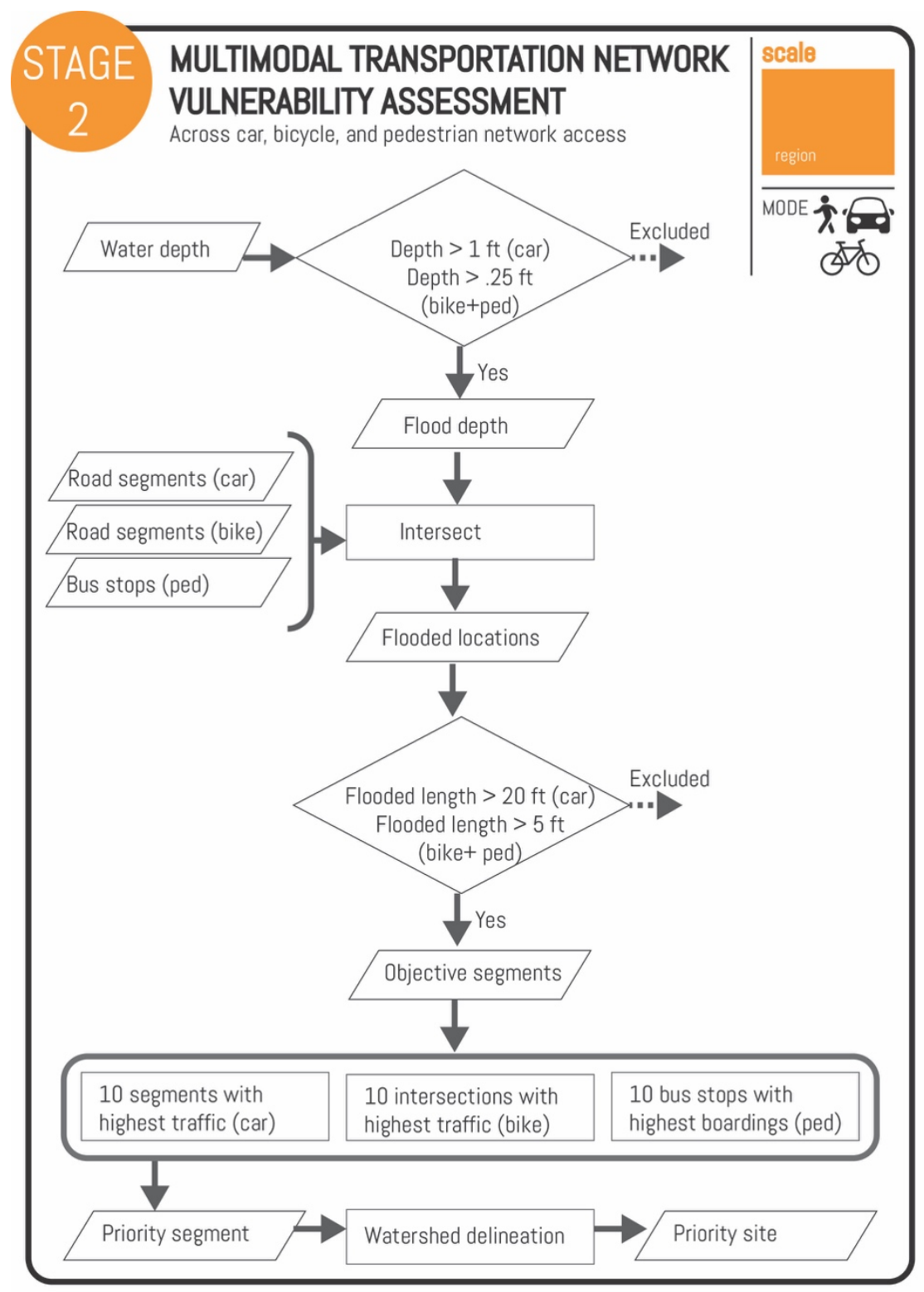

Figure 2.4 Flow chart of priority segments and sites selection

\subsubsection{Research Areas and Low Income Neighborhood Statistics}

In 2017, the average Tucson median household income (MHI) was $\$ 51,425$. The average poverty rate was $24 \%$. Tables $1.3,1.4$, and 1.5 summarize the $\mathrm{MHI}$ and poverty rates for the thirty research areas. Overall, $93 \%$ of the 30 research priority areas were in areas with MHIs averages below the Tucson average, with vehicles at $100 \%$, bicycles at $90 \%$ and pedestrians bus stops at $90 \%$. The poverty rates held similar comparisons. 
Table 2.1 Vehicle network research priority sites socioeconomic statistics

\begin{tabular}{|c|c|c|c|c|c|c|c|c|}
\hline $\begin{array}{l}\text { Priority } \\
\text { Site \# }\end{array}$ & $\begin{array}{l}\text { Count of } \\
\text { Block Group } \\
\text { Intersected }\end{array}$ & Min MHI & Max MHI & Ave MHI & $\begin{array}{l}\text { Min } \\
\text { Ratio } \\
\text { Poverty } \\
\end{array}$ & $\begin{array}{l}\text { Max } \\
\text { Ratio } \\
\text { Poverty } \\
\end{array}$ & $\begin{array}{l}\text { Ave } \\
\text { Ratio } \\
\text { Poverty } \\
\end{array}$ & $\begin{array}{l}\text { Poverty } \\
\text { Pop }\end{array}$ \\
\hline 1 & 13 & $\$ 24,583$ & $\$ 79,884$ & $\$ 43,313$ & $6 \%$ & $54 \%$ & $28 \%$ & 4,143 \\
\hline 2 & 6 & $\$ 13,274$ & $\$ 67,000$ & $\$ 35,753$ & $3 \%$ & $40 \%$ & $23 \%$ & 1,423 \\
\hline 3 & 12 & $\$ 21,513$ & $\$ 57,564$ & $\$ 32,664$ & $6 \%$ & $38 \%$ & $27 \%$ & 3,908 \\
\hline 4 & 12 & $\$ 12,330$ & $\$ 43,656$ & $\$ 32,781$ & $18 \%$ & $56 \%$ & $32 \%$ & 4,260 \\
\hline 5 & 8 & $\$ 15,196$ & $\$ 49,938$ & $\$ 31,733$ & $2 \%$ & $47 \%$ & $31 \%$ & 3,226 \\
\hline 6 & 9 & $\$ 23,300$ & $\$ 53,068$ & $\$ 36,160$ & $6 \%$ & $54 \%$ & $34 \%$ & 3,974 \\
\hline 7 & 12 & $\$ 16,481$ & $\$ 57,564$ & $\$ 32,048$ & $14 \%$ & $57 \%$ & $33 \%$ & 4,470 \\
\hline 8 & 9 & $\$ 16,481$ & $\$ 57,564$ & $\$ 33,030$ & $14 \%$ & $57 \%$ & $31 \%$ & 3,016 \\
\hline 9 & 14 & $\$ 16,481$ & $\$ 57,564$ & $\$ 30,845$ & $14 \%$ & $57 \%$ & $33 \%$ & 5,191 \\
\hline 10 & 11 & $\$ 14,600$ & $\$ 39,345$ & $\$ 27,245$ & $7 \%$ & $75 \%$ & $32 \%$ & 4,268 \\
\hline
\end{tabular}

Table 2.2 Bicycle network research priority sites socioeconomic statistics

\begin{tabular}{r|r|r|r|r|r|r|r|r}
\hline $\begin{array}{l}\text { Priority } \\
\text { Site \# }\end{array}$ & $\begin{array}{l}\text { lount of } \\
\text { Block Group } \\
\text { Intersected }\end{array}$ & Min MHI & Max MHI & Ave MHI & $\begin{array}{l}\text { Min } \\
\text { Ratio } \\
\text { Poverty }\end{array}$ & $\begin{array}{l}\text { Max } \\
\text { Ratio } \\
\text { Poverty }\end{array}$ & $\begin{array}{l}\text { Ave } \\
\text { Ratio } \\
\text { Poverty }\end{array}$ & $\begin{array}{l}\text { Poverty } \\
\text { Pop }\end{array}$ \\
\hline 1 & 6 & $\$ 0$ & $\$ 48,047$ & $\$ 21,521$ & $0 \%$ & $65 \%$ & $30 \%$ & 920 \\
\hline 2 & 8 & $\$ 0$ & $\$ 74,167$ & $\$ 43,171$ & $0 \%$ & $65 \%$ & $21 \%$ & 1,282 \\
\hline 3 & 8 & $\$ 0$ & $\$ 48,047$ & $\$ 22,432$ & $0 \%$ & $65 \%$ & $32 \%$ & 1,692 \\
\hline 4 & 4 & $\$ 13,750$ & $\$ 50,968$ & $\$ 32,435$ & $26 \%$ & $69 \%$ & $43 \%$ & 2,500 \\
\hline 5 & 7 & $\$ 0$ & $\$ 48,047$ & $\$ 20,283$ & $7 \%$ & $65 \%$ & $39 \%$ & 1,830 \\
\hline 6 & 2 & $\$ 71,181$ & $\$ 74,167$ & $\$ 72,674$ & $8 \%$ & $8 \%$ & $8 \%$ & 140 \\
\hline 7 & 10 & $\$ 0$ & $\$ 74,167$ & $\$ 38,424$ & $0 \%$ & $68 \%$ & $28 \%$ & 2,040 \\
\hline 8 & 7 & $\$ 0$ & $\$ 48,047$ & $\$ 20,283$ & $7 \%$ & $65 \%$ & $39 \%$ & 1,830 \\
\hline 9 & 4 & $\$ 0$ & $\$ 48,047$ & $\$ 19,351$ & $7 \%$ & $65 \%$ & $36 \%$ & 456 \\
\hline 10 & 6 & $\$ 0$ & $\$ 48,047$ & $\$ 17,074$ & $7 \%$ & $73 \%$ & $53 \%$ & 2,127 \\
\hline
\end{tabular}

Table 2.3 Pedestrian bus stop network research priority sites socioeconomic statistics

\begin{tabular}{r|r|r|r|r|r|r|r|r}
\hline $\begin{array}{l}\text { Priority } \\
\text { Site \# }\end{array}$ & $\begin{array}{l}\text { lount of } \\
\text { Block Group } \\
\text { Intersected }\end{array}$ & \multicolumn{1}{|l|}{ Min MHI } & Max MHI & Ave MHI & $\begin{array}{l}\text { Min } \\
\text { Ratio } \\
\text { Poverty }\end{array}$ & $\begin{array}{l}\text { Max } \\
\text { Ratio } \\
\text { Poverty }\end{array}$ & $\begin{array}{l}\text { Ave Ratio } \\
\text { Poverty }\end{array}$ & $\begin{array}{l}\text { Poverty } \\
\text { Pop }\end{array}$ \\
\hline 1 & 5 & $\$ 14,245$ & $\$ 47,841$ & $\$ 33,223$ & $22 \%$ & $54 \%$ & $32 \%$ & 1,433 \\
\hline 2 & 11 & $\$ 16,481$ & $\$ 38,333$ & $\$ 27,431$ & $17 \%$ & $57 \%$ & $33 \%$ & 3,861 \\
\hline 3 & 8 & $\$ 0$ & $\$ 48,047$ & $\$ 20,450$ & $7 \%$ & $65 \%$ & $40 \%$ & 2,156 \\
\hline 4 & 9 & $\$ 16,481$ & $\$ 102,955$ & $\$ 52,081$ & $3 \%$ & $57 \%$ & $26 \%$ & 2,828 \\
\hline
\end{tabular}




\begin{tabular}{r|r|r|r|r|r|r|r|r}
\hline 5 & 8 & $\$ 0$ & $\$ 74,167$ & $\$ 43,171$ & $0 \%$ & $65 \%$ & $21 \%$ & 1,282 \\
\hline 6 & 8 & $\$ 10,604$ & $\$ 29,515$ & $\$ 17,957$ & $7 \%$ & $76 \%$ & $50 \%$ & 4,067 \\
\hline 7 & 12 & $\$ 16,004$ & $\$ 85,833$ & $\$ 32,849$ & $0 \%$ & $58 \%$ & $30 \%$ & 4,528 \\
\hline 8 & 7 & $\$ 19,375$ & $\$ 63,906$ & $\$ 48,807$ & $0 \%$ & $30 \%$ & $13 \%$ & 1,072 \\
\hline 9 & 10 & $\$ 15,777$ & $\$ 70,000$ & $\$ 43,182$ & $0 \%$ & $66 \%$ & $28 \%$ & 3,380 \\
\hline 10 & 5 & $\$ 13,946$ & $\$ 49,938$ & $\$ 23,953$ & $2 \%$ & $66 \%$ & $45 \%$ & 4,006 \\
\hline
\end{tabular}

\subsection{STAGE 3: INTEGRATED HYDROLOGIC-TRANSPORTATION SIMULATIONS FOR THIRTY GI SCENARIOS}

\subsubsection{Research Area Delineation}

Stage 3 completed integrated transportation and hydrological simulations for the thirty research area scenarios identified from the Stage 1 and 2 results. The aim of the third stage was to evaluate the change in transportation network accessibility during a 1hour, 5-year event after comprehensive neighborhood-scale GI implementation. To finalize each of the defined research priority areas for the Gl implementation in Stage 3, several hydrological factors were taken into consideration. First, the point(s) where water flows out of the research priority area, or pour point(s), were selected and used to delineate the watershed that covered the research area. This process was completed using ArcGIS Hydrology Analysis, with the assumption that water only flows in one direction, which is from higher elevation to lower elevation. Second, there were two cases where an isolated hydrological area was not able to be delineated and the use of hydrographs were required. In one case, when the delineated watershed from the pour points was too large to be considered as a research area (no more than 1 square mile), a hydrograph was set along a 1-mile buffer from the potential research area in the 20foot model to account for the water flow outside of the 1-mile buffer. The second case was when the delineated watershed was not self-contained and had water flows that went across the delineated sub-watershed and contributed to the flooding condition. This process was completed using FLO-2D, which assumes that water flows in eight directions.

\subsubsection{GI Implementation}

In each of the thirty scenarios, GI was implemented in all available right-of-way throughout the neighborhood-scale, hydrologically defined research area. Figure 2.5 shows typical sections for these roadside basin GI implementations following design standards from Pima County and the National Association of City Transportation Officials (NACTO). As the analysis was performed at a neighborhood scale with a 5foot grid, design features smaller that the grid size (such as inlets and outlets) were not incorporated into the design standards. Areas of road land cover, parcel region, and washes were erased from the research area to pursue the potential GI areas using GIS techniques. GI roadside basins were implemented at a depth of 9 inches. Such 
implementation would require inlets and outlets (such as curb cuts, culverts, or scuppers), armoring these openings with rock of concrete, and removing substrate to reduce curbside elevation of the right-of-way by 9 inches (the maximum allowed by County code). County code stipulates a 9 inch maximum depth to control the levels and duration of standing water in the GSI to minimize mosquito propagation.

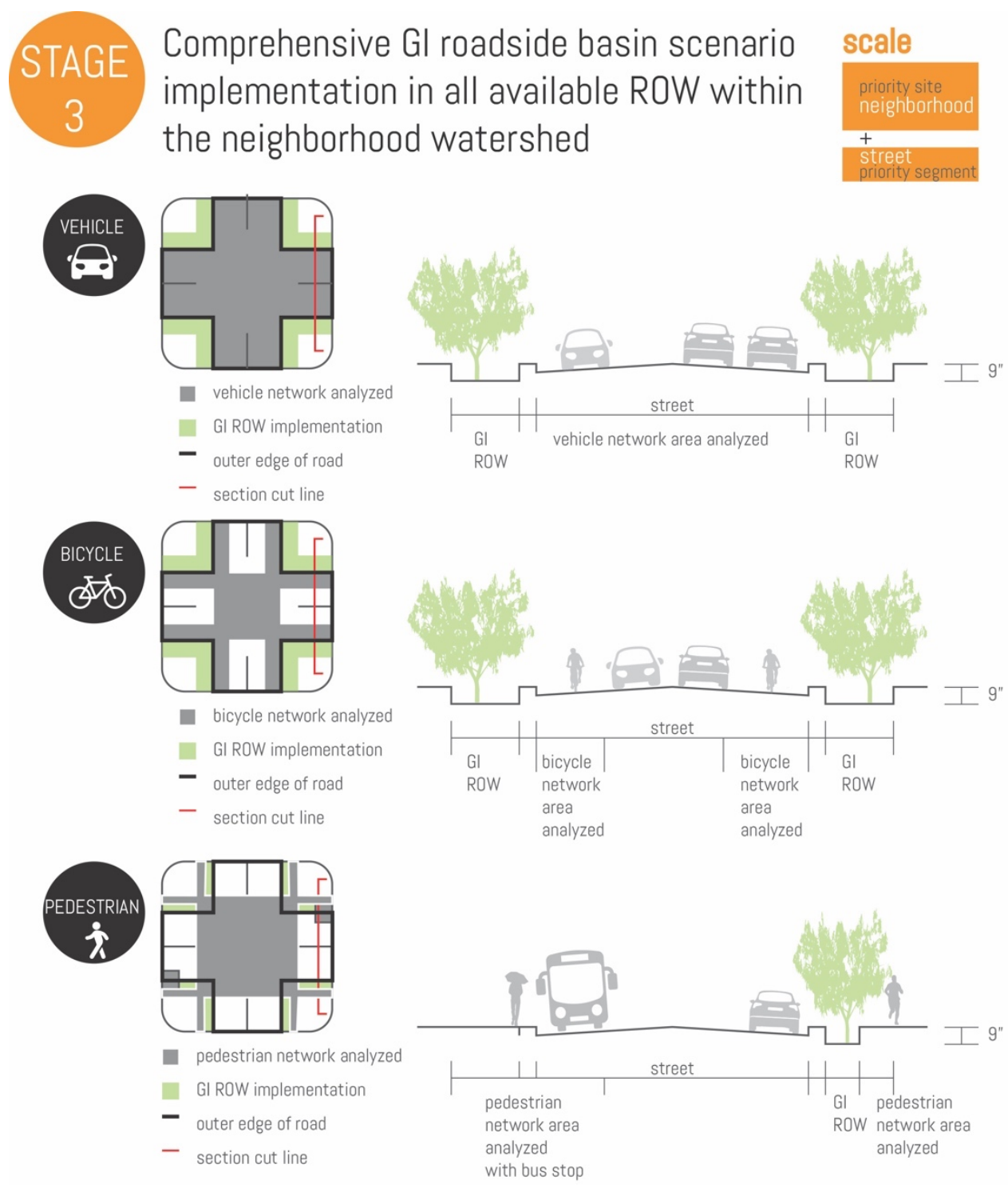

Figure 2.5 Typical roadside basin Gi implementation for each mode of transportation

An example for each of the transportation systems (vehicle, bicycle, and pedestrian access to bus stops) are shown below. Figures 2.6 and 2.7 display the flooding condition from the 1-hour, 5-year event from Stage 1. The flooded road segment is boxed by the black dash line, which is one of the research locations from the process 2.1 (\#2 in the traffic scenario). In this example, two pour points were selected and delineated two sub-watersheds, which is divided by the purple line. With the flooding condition, we can see the water flows from the left sub-watershed across the purple line 
and contributed to the flooding condition of the research location. Thus, the left subwatershed is also included in the research area for research location \#2. The hydrograph shown as blue line were set along the 1 mile buffer from the research location \#2 to catch up the flows.
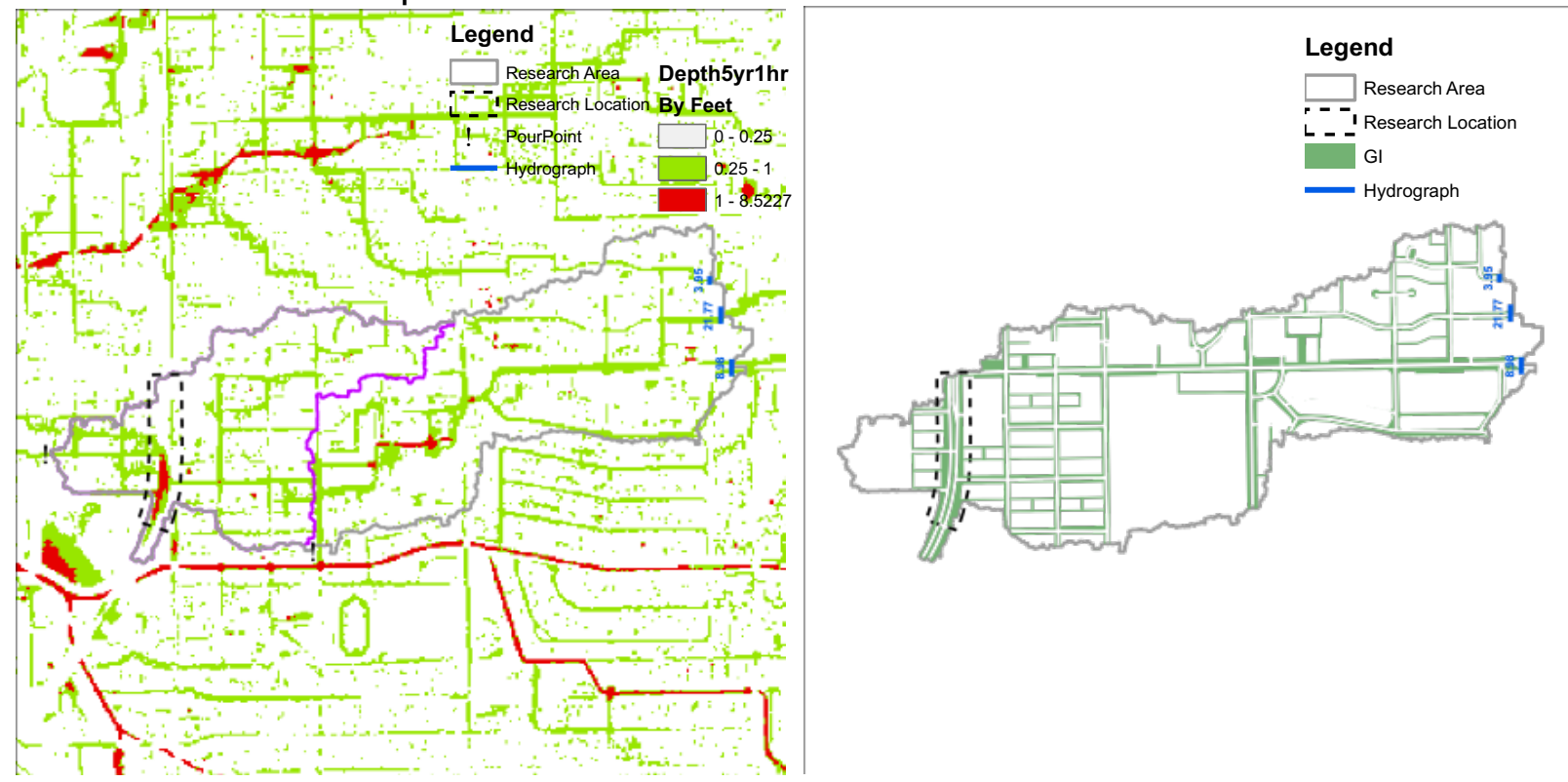

Figure 2.6 Traffic scenario \#2 - Priority site and segment (left)

Figure $2.7 \mathrm{GI}$ implementation across the priority site(right)

Figures 2.8 and 2.9 show the research area and $\mathrm{Gl}$ implementation for the research location \#7 in the bicycle scenario. In this case, the research area delineated by the several pour points is self-contained, and GI were set on the upstream to the research location within 1 mile distance.

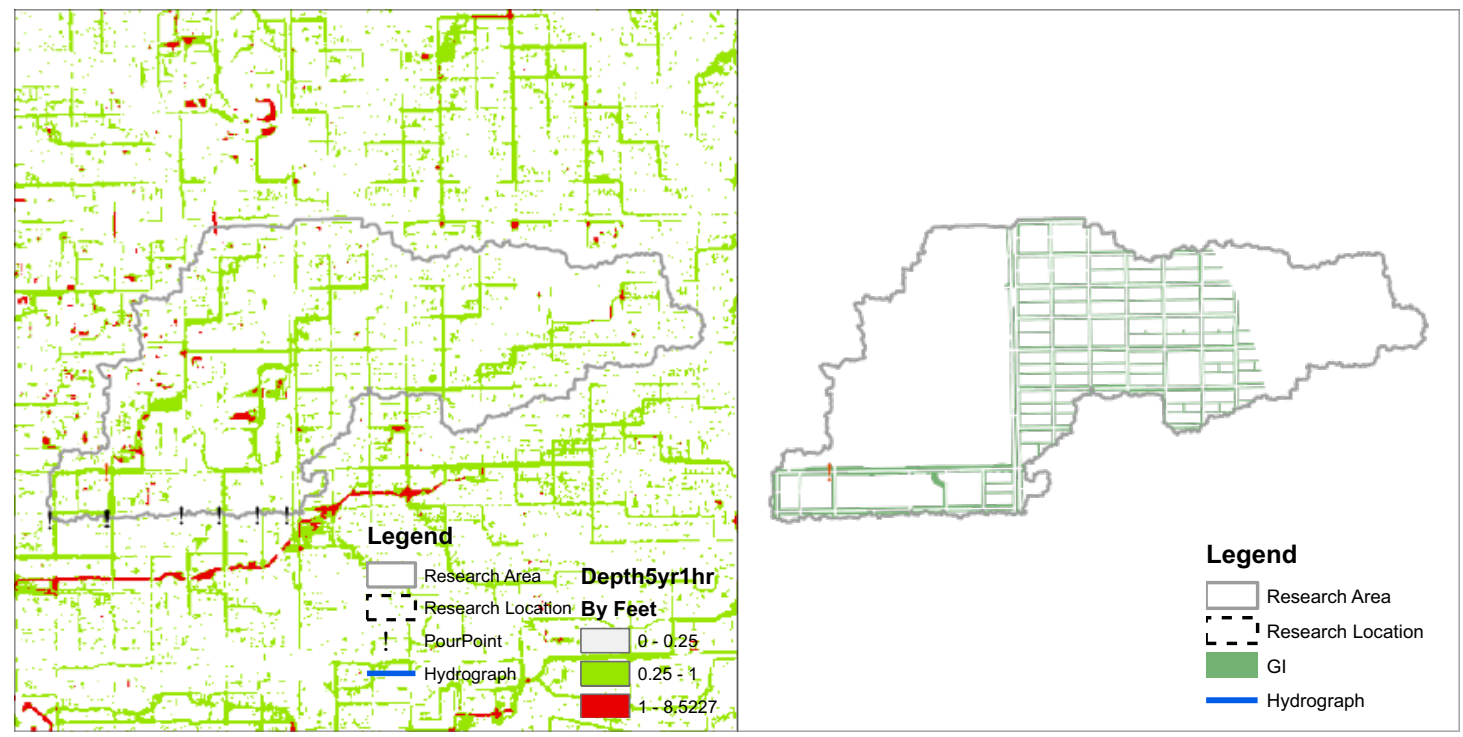

Figure 2.8 Bicycle scenario \#7 - Priority site and segment (left) 
Figure $2.9 \mathrm{GI}$ implementation across the priority site (right)

Figures 2.10 and 2.11 shows the example of research location \#10 in the pedestrian scenario. In this example, the sub-watershed delineated by the pour point is not selfcontained and has water flows outside of the boundary.

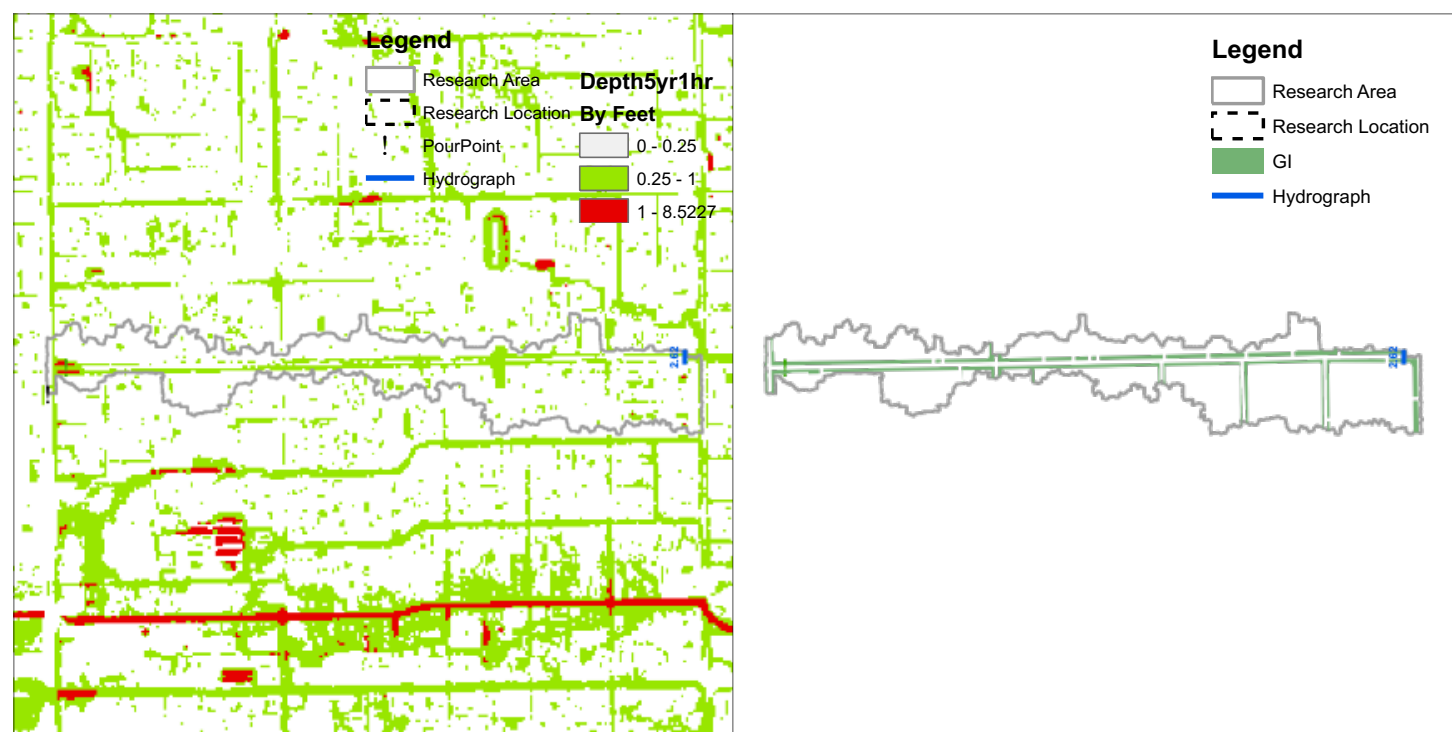

Figure 2.10 Pedestrian Scenario \#10 - Priority site and segment (left)

Figure $2.11 \mathrm{GI}$ implementation across the priority site (right)

\subsection{STAGE 4: IMPACT ASSESSMENT WITH RESULTING DESIGN PRIORITIES}

The final stage of the research method analyzed the modeling results for impact on access to the three transportation networks at the neighborhood and street scale. Based on these results, five key GI design performance priorities were identified to maximize the accessibility of the multimodal transportation through GI implementation. Flood manager, transportation planners, and urban designers can employ these design priorities in future GI projects toward maximum accessibility to the multimodal network.

\subsection{TECHNICAL REVIEW COMMITTEE}

Due to the multi-discipline and multi-sector character of the work, a technical review committee for the research and design scenarios was codified. Below are the members:

- Robin Raine, Interim Director, Tucson Department of Transportation (TDOT)

- Eric Shepp, Deputy Director, Pima County Regional Flood Control District (PCRFCD)

- Jacob Prietto, Hydrologic Modeler, Pima County Regional Flood Control District (PCRFCD)

- James MacAdam, Superintendent, City of Tucson Water Department 
This committee of City and County staff experts provided critical feedback on practical aspects of the hydrological modelling across typical Tucson urban conditions as well as technical feedback while formulating the $\mathrm{Gl}$ installation scenarios for the right-of-way. 


\subsection{RESULTS: THIRTY PRIORITY SITES AND SEGMENTS}

This section provides results for the thirty GI scenarios implemented in Stage 3 (ten priority sites and segments for each of bicycle, vehicle, and pedestrian bus stop access) and their implications for the Stage 4 impact assessment. Results are structured by the three transportation networks studied. Each set of results reports both the neighborhood-scale (priority site) and street-scale (priority segment) impacts from the GI installation on the hydrological and transportation systems.

\subsection{VEHICULAR TRAFFIC: TEN CAR PRIORITY SITES AND SEGMENTS}

Figure 3.1 illustrates how the mitigating effects of GI were evaluated. Two areas of analysis are represented. The first is the selected priority segment in the red dashed line box identified during Stage 1 and 2 (see Part 2.2 Research Location Selection). The second is all the gray area identified in Stage 2 and 3, which is the neighborhood-scale priority site area. Table 3.1 to Table 3.4 summarize and compare the mitigating effects of the Gl implementation for the ten car priority sites and segments listed in descending order of traffic volume. Roads with flooding at or over one-foot were considered impassable; roads with flooding under one-foot were deemed accessible. GI was implemented in all available right-of-ways throughout the priority site (see Figure 2.5 section).

Table 3.1 Basic information for each research site

\begin{tabular}{|c|c|c|c|}
\hline Priority Site \# & $\begin{array}{l}\text { Total Area of Delineated Sub-basin } \\
\text { (SQFT) }\end{array}$ & $\begin{array}{l}\text { \%Area of } \\
\text { ROW for GI } \\
\text { application }\end{array}$ & \%Impervious \\
\hline 1 & $27,493,825$ & $11.96 \%$ & $51.26 \%$ \\
\hline 2 & $9,679,250$ & $15.37 \%$ & $67.86 \%$ \\
\hline 3 & $19,934,375$ & $8.99 \%$ & $46.36 \%$ \\
\hline 4 & $20,591,700$ & $9.17 \%$ & $50.27 \%$ \\
\hline 5 & $27,583,775$ & $10.05 \%$ & $51.28 \%$ \\
\hline 6 & $22,447,300$ & $8.55 \%$ & $37.90 \%$ \\
\hline 7 & $18,930,500$ & $11.64 \%$ & $48.43 \%$ \\
\hline 8 & $24,816,875$ & $11.27 \%$ & $48.73 \%$ \\
\hline 9 & 19728925 & $10.22 \%$ & $48.01 \%$ \\
\hline 10 & 1868525 & $15.10 \%$ & $60.96 \%$ \\
\hline
\end{tabular}




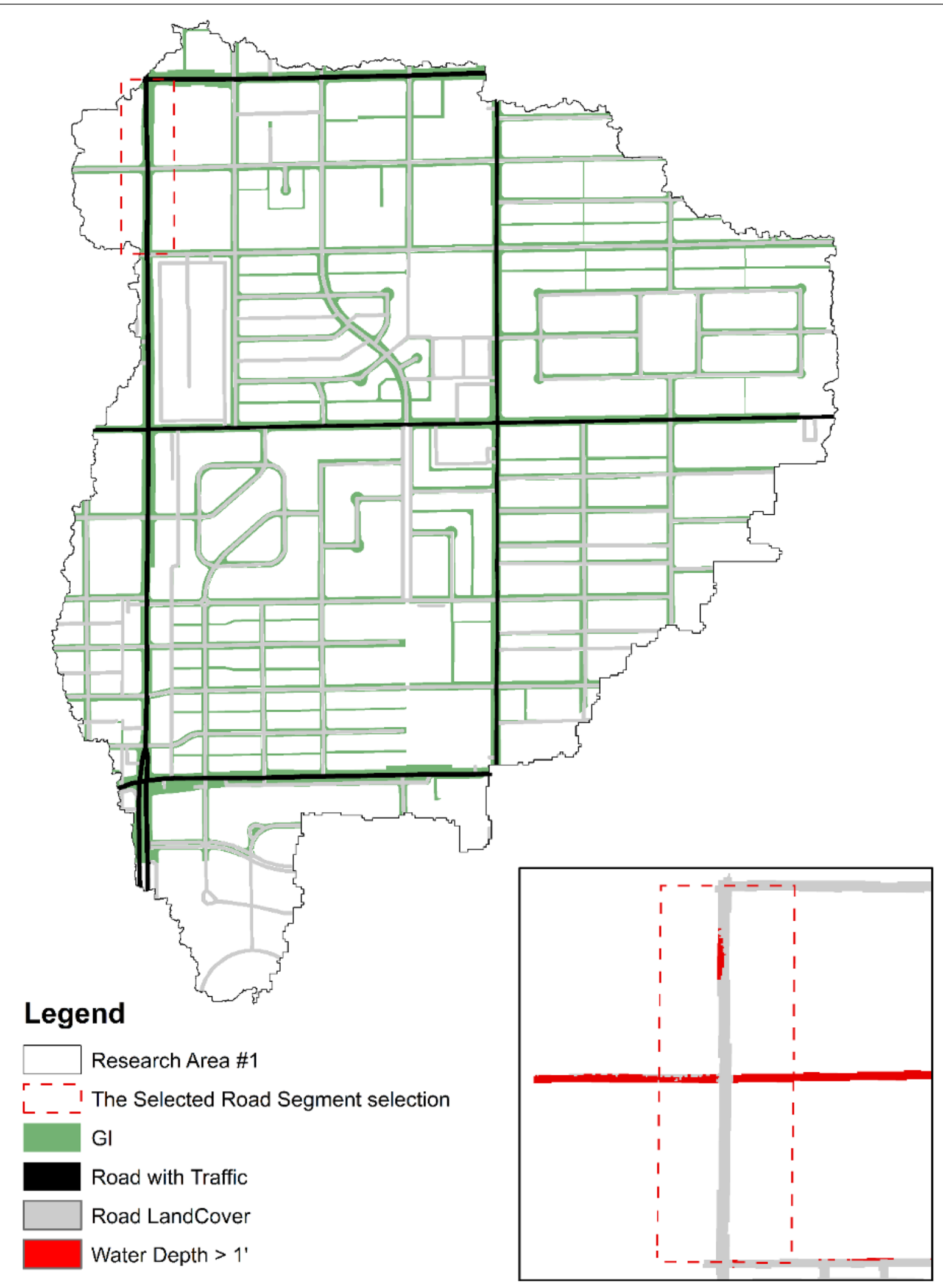

Figure 3.1 Results evaluation 
Table 3.2 Comparison between priority segments before and after $\mathrm{Gl}$

\begin{tabular}{r|l|l|r|r|r|r|r}
\hline & $\begin{array}{l}\text { Area of } \\
\text { Prior } \\
\text { Road } \\
\text { Segment } \\
\text { Priority } \\
\text { Site \# }\end{array}$ & $\begin{array}{l}\text { Daily } \\
\text { (Sraffic } \\
\text { (Cars/ } \\
\text { Day) }\end{array}$ & $\begin{array}{l}\text { \%Area > } \\
\text { 1' (Pre) }\end{array}$ & $\begin{array}{l}\text { \%Area > } \\
\text { 1' (Post) }\end{array}$ & $\begin{array}{l}\text { lanes } \\
\text { Passable } \\
\text { (Pre) }\end{array}$ & $\begin{array}{l}\text { Lanes } \\
\text { Passable } \\
\text { (Post) }\end{array}$ & $\begin{array}{l}\text { Mitigated } \\
\text { Area } \\
\text { (SQFT) }\end{array}$ \\
\hline 1 & 47,975 & 39,141 & $5.37 \%$ & $8.18 \%$ & 3 & 2 & $-1,350$ \\
\hline 2 & 93,975 & 35,729 & $19.77 \%$ & $8.43 \%$ & 1 & 4 & 10,650 \\
\hline 3 & 46,850 & 31,358 & $1.39 \%$ & $0.00 \%$ & 2 & 5 & 650 \\
\hline 4 & 65,775 & 29,886 & $5.51 \%$ & $3.19 \%$ & 0 & 1 & 1,525 \\
\hline 5 & 48,475 & 27,754 & $3.20 \%$ & $2.68 \%$ & 1 & 2 & 250 \\
\hline 6 & 47,125 & 26,589 & $13.69 \%$ & $2.23 \%$ & 4 & 4 & 5,400 \\
\hline 7 & 47,725 & 26,589 & $44.05 \%$ & $5.87 \%$ & 3 & 4 & 18,225 \\
\hline 8 & 47,075 & 26,589 & $33.56 \%$ & $1.22 \%$ & 1 & 4 & 15,225 \\
\hline 9 & 47,075 & 26,589 & $41.90 \%$ & $24.06 \%$ & 0 & 0 & 8,400 \\
\hline 10 & 45,750 & 25,711 & $10.33 \%$ & $10.05 \%$ & 0 & 0 & 125 \\
\hline
\end{tabular}

Table 3.3 Comparison between priority segments with traffic information before and after $\mathrm{GI}$ implementation

\begin{tabular}{r|r|r|r|r}
\hline \multicolumn{1}{c|}{$\begin{array}{l}\text { Priority } \\
\text { Site \# }\end{array}$} & $\begin{array}{l}\text { Total Area of } \\
\text { Roads with } \\
\text { Traffic } \\
\text { Information } \\
\text { (SQFT) }\end{array}$ & $\begin{array}{l}\text { \%Area > 1' } \\
\text { (Pre) }\end{array}$ & $\begin{array}{l}\text { \%Area } \\
\text { > 1' } \\
\text { (Post) }\end{array}$ & $\begin{array}{l}\text { Mitigated } \\
\text { Area (SQFT) }\end{array}$ \\
\hline 1 & 765,625 & $0.59 \%$ & $0.52 \%$ & 550 \\
\hline 2 & 337,850 & $5.50 \%$ & $2.35 \%$ & 10,650 \\
\hline 3 & 445,650 & $21.97 \%$ & $0.15 \%$ & 97,250 \\
\hline 4 & 507,125 & $17.19 \%$ & $7.60 \%$ & 48,600 \\
\hline 5 & 727,725 & $13.90 \%$ & $5.73 \%$ & 59,425 \\
\hline 6 & 460,625 & $1.80 \%$ & $0.33 \%$ & 6,800 \\
\hline 7 & 589,700 & $3.09 \%$ & $0.34 \%$ & 16,207 \\
\hline 8 & 863,675 & $4.49 \%$ & $0.33 \%$ & 35,950 \\
\hline 9 & 599,250 & $15.54 \%$ & $2.80 \%$ & 76,325 \\
\hline 10 & 121,775 & $3.88 \%$ & $3.78 \%$ & 125 \\
\hline
\end{tabular}

Table 3.4 Comparison between all the priority sites before and after $\mathrm{Gl}$ implementation 


\begin{tabular}{|c|c|c|c|c|}
\hline $\begin{array}{l}\text { Research } \\
\text { Location } \\
\text { \# }\end{array}$ & $\begin{array}{l}\text { Total Area } \\
\text { of All Road } \\
\text { (SQFT) }\end{array}$ & $\begin{array}{l}\text { \%Area > 1' } \\
\text { (Existing) }\end{array}$ & $\begin{array}{l}\text { \%Area > 1' } \\
\text { (GI) }\end{array}$ & $\begin{array}{l}\text { Mitigated } \\
\text { Area (SQFT) }\end{array}$ \\
\hline 1 & $3,825,725$ & $2.09 \%$ & $1.01 \%$ & 41,175 \\
\hline 2 & $1,224,950$ & $1.85 \%$ & $0.81 \%$ & 12,775 \\
\hline 3 & $1,977,550$ & $6.14 \%$ & $0.12 \%$ & 119,000 \\
\hline 4 & $2,504,500$ & $9.39 \%$ & $6.58 \%$ & 70,400 \\
\hline 5 & $3,921,000$ & $6.54 \%$ & $3.63 \%$ & 114,100 \\
\hline 6 & $1,846,600$ & $0.45 \%$ & $0.09 \%$ & 6,775 \\
\hline 7 & $2,066,675$ & $3.09 \%$ & $0.34 \%$ & 56,800 \\
\hline 8 & $2,824,275$ & $2.82 \%$ & $0.78 \%$ & 57,525 \\
\hline 9 & $2,310,350$ & $4.49 \%$ & $0.96 \%$ & 81,500 \\
\hline 10 & 370,350 & $1.30 \%$ & $1.26 \%$ & 125 \\
\hline
\end{tabular}

\subsection{BICYCLE FLOWS: TEN BICYCLE PRIORITY SITES AND SEGMENTS}

Bicycle flow data was collected at street intersections for all flow directions (i.e. typically following the orientations of NE, SE, NW, SW direction of travel). Figure 3.2 presents an example analysis of a bicycle priority site and segment with the identified intersection. Intersections are included in the bicycle network by linking the outer points of all bicycle network points and including the intersection for protected left turns. Water depth at or over 3 inches ( 0.25 feet) was considered as flooded and impassable, and water depth less than 3 inches ( 0.25 feet) was considered as passable. The bicycle area of travel was assumed to have a width of ten feet when a shared road condition and a width of five feet when a designated lane condition (see Figure 2.5 section). Tables 3.5-3.10 present results across the ten bicycle priority sites and segments and the relative impacts of comprehensive $\mathrm{GI}$ implementation.

Table 3.5 Basic information of each research site

\begin{tabular}{|c|c|c|c|}
\hline Priority Site \# & $\begin{array}{l}\text { Total Area of Delineated Sub- } \\
\text { basin (SQFT) }\end{array}$ & $\%$ Area of GI & \%Impervious \\
\hline 1 & $6,696,900$ & $3.50 \%$ & $71.15 \%$ \\
\hline 2 & $12,939,975$ & $8.85 \%$ & $56.30 \%$ \\
\hline 3 & $8,897,225$ & $7.16 \%$ & $71.45 \%$ \\
\hline 4 & $5,058,000$ & $13.23 \%$ & $50.15 \%$ \\
\hline 5 & $8,509,200$ & $13.48 \%$ & $68.99 \%$ \\
\hline 6 & $3,191,575$ & $12.55 \%$ & $34.03 \%$ \\
\hline 7 & $15,964,375$ & $9.12 \%$ & $56.30 \%$ \\
\hline 8 & $10,910,675$ & $14.42 \%$ & $65.93 \%$ \\
\hline 9 & $2,389,050$ & $3.59 \%$ & $77.61 \%$ \\
\hline
\end{tabular}




\begin{tabular}{r|r|r|r}
\hline 10 & $7,323,525$ & $5.40 \%$ & $70.57 \%$ \\
\hline
\end{tabular}

Figure 3.2 Water depth comparison for bicycle scenario \#7 before (left) and after (right) GI.

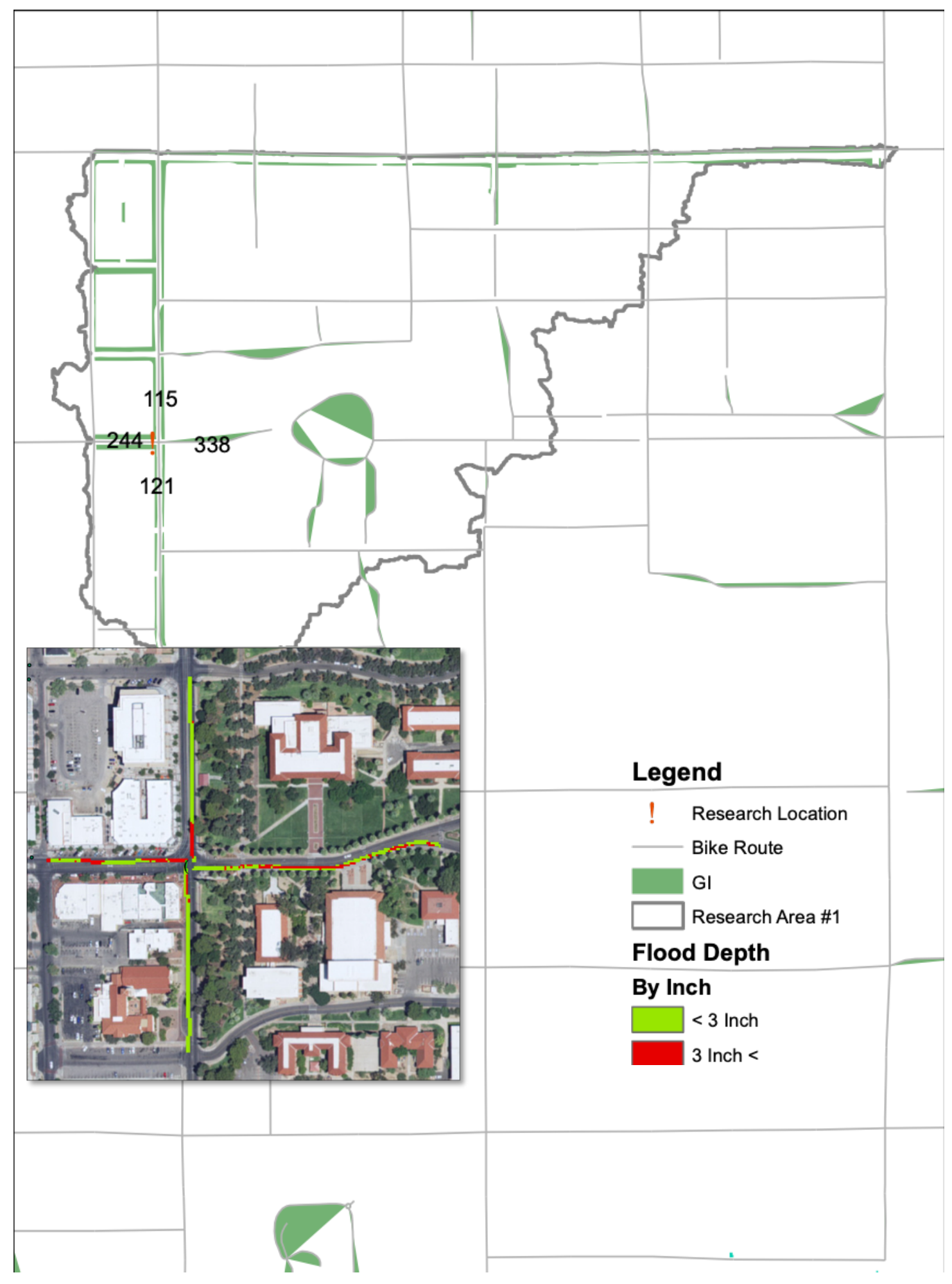


Table 3.6 Comparison among priority segments to the east before and after GI implementation

\begin{tabular}{r|r|r|r|r|r|l}
\hline $\begin{array}{r}\text { Priority } \\
\text { Site \# }\end{array}$ & $\begin{array}{l}\text { Bike Flow } \\
\text { to East } \\
\text { (Count/ } \\
\text { Day) }\end{array}$ & $\begin{array}{l}\text { Area of } \\
\text { Bike Lane } \\
\text { (SQFT) }\end{array}$ & $\begin{array}{l}\text { \%Area > } \\
\text { 3" (Pre) }\end{array}$ & $\begin{array}{l}\text { \%Area > } \\
\text { 3" (Post) }\end{array}$ & $\begin{array}{l}\text { Mitigated } \\
\text { Area } \\
\text { (SQFT) }\end{array}$ & Bike Route Type \\
\hline 1 & 338 & 6,250 & $36.40 \%$ & $36.40 \%$ & 0 & Residential Streets \\
\hline 2 & 349 & 4,025 & $86.34 \%$ & $16.15 \%$ & 2825 & $\begin{array}{l}\text { Bike Blvd/Shared } \\
\text { Lane Markings }\end{array}$ \\
\hline 3 & 310 & 4,525 & $86.74 \%$ & $3.87 \%$ & 3750 & $\begin{array}{l}\text { Bike Blvd/Shared } \\
\text { Lane Markings }\end{array}$ \\
\hline 5 & 19 & 2,675 & $8.41 \%$ & $11.21 \%$ & -75 & $\begin{array}{l}\text { Bike Route with } \\
\text { Striped Shoulder }\end{array}$ \\
\hline 6 & 187 & 4,625 & $100.00 \%$ & $10.81 \%$ & 4125 & $\begin{array}{l}\text { Bike Blvd/Shared } \\
\text { Lane Markings }\end{array}$ \\
\hline 7 & 241 & 4,300 & $100.00 \%$ & $20.93 \%$ & 3400 & $\begin{array}{l}\text { Bike Blvd/Shared } \\
\text { Lane Markings }\end{array}$ \\
\hline 8 & 5 & 8,675 & $46.40 \%$ & $4.32 \%$ & 3650 & <Null> \\
\hline 9 & 162 & 2,225 & $0.00 \%$ & $0.00 \%$ & $\begin{array}{l}\text { Bike Blvd/Shared } \\
\text { Lane Markings }\end{array}$ \\
\hline 10 & 113 & 8,975 & $98.33 \%$ & $98.33 \%$ & 0 & Residential Streets \\
\hline & 12 & 8,050 & $14.60 \%$ & $0.00 \%$ & 1175 & $\begin{array}{l}\text { Bike Route with } \\
\text { Striped Shoulder }\end{array}$ \\
\hline
\end{tabular}

Table 3.7 Comparison among priority segments to the north before and after GI implementation

\begin{tabular}{|c|c|c|c|c|c|c|}
\hline $\begin{array}{l}\text { Priority } \\
\text { Site \# }\end{array}$ & $\begin{array}{l}\text { Bike } \\
\text { Flow to } \\
\text { North } \\
\text { (Count/ } \\
\text { Day) }\end{array}$ & $\begin{array}{l}\text { Area of } \\
\text { Bike } \\
\text { Lane } \\
\text { (SQFT) }\end{array}$ & $\begin{array}{l}\text { \%Area > } \\
\text { 3" (Pre) }\end{array}$ & $\begin{array}{l}\text { \%Area } \\
>3 " \\
\text { (Post) }\end{array}$ & $\begin{array}{l}\text { Mitigated } \\
\text { Area } \\
\text { (SQFT) }\end{array}$ & BikeRouteType \\
\hline 1 & 115 & 4,625 & $75.14 \%$ & $18.92 \%$ & 2600 & $\begin{array}{l}\text { Bike Route with Striped } \\
\text { Shoulder }\end{array}$ \\
\hline 2 & 14 & 2,325 & $100.00 \%$ & $89.25 \%$ & 250 & $\begin{array}{l}\text { Bike Route with Striped } \\
\text { Shoulder }\end{array}$ \\
\hline 3 & 6 & 4,575 & $16.39 \%$ & $8.74 \%$ & 350 & $<$ Null $>$ \\
\hline 4 & 225 & 3,425 & $100.00 \%$ & $100.00 \%$ & 0 & $\begin{array}{l}\text { Bike Route with Striped } \\
\text { Shoulder }\end{array}$ \\
\hline 5 & 101 & 4,500 & $16.67 \%$ & $7.78 \%$ & 400 & $\begin{array}{l}\text { Bike Blvd/Shared Lane } \\
\text { Markings }\end{array}$ \\
\hline 6 & 9 & 1,800 & $11.11 \%$ & $12.50 \%$ & -25 & $\begin{array}{l}\text { Bike Route with Striped } \\
\text { Shoulder }\end{array}$ \\
\hline 7 & 234 & 8,325 & $14.11 \%$ & $15.32 \%$ & -100 & Residential Streets \\
\hline 8 & 39 & 4,500 & $19.44 \%$ & $7.78 \%$ & 525 & Shared Lane Markings \\
\hline 9 & 51 & 3,600 & $31.25 \%$ & $31.25 \%$ & 0 & Residential Streets \\
\hline 10 & 133 & 4,350 & $7.47 \%$ & $3.45 \%$ & 175 & $\begin{array}{l}\text { Bike Route with Striped } \\
\text { Shoulder }\end{array}$ \\
\hline
\end{tabular}


Table 3.8 Comparison among priority segments to the south before and after GI implementation

\begin{tabular}{rr|r|r|r|r|l|l}
\hline $\begin{array}{r}\text { Priority } \\
\text { Site \# }\end{array}$ & $\begin{array}{l}\text { Bike Flow to } \\
\text { South } \\
\text { (Count/ Day) }\end{array}$ & $\begin{array}{l}\text { Area of } \\
\text { Bike Lane } \\
\text { (SQFT) }\end{array}$ & $\begin{array}{l}\text { \%Area > (Pre) } \\
\text { 3" }\end{array}$ & $\begin{array}{l}\text { \%Area } \\
\text { > 3" } \\
\text { (Post) }\end{array}$ & $\begin{array}{l}\text { Mitigate } \\
\text { d Area } \\
\text { (SQFT) }\end{array}$ & BikeRouteType \\
\hline 1 & 121 & 4,600 & $47.83 \%$ & $6.52 \%$ & 1,900 & Residential Streets \\
\hline 2 & 14 & 4,625 & $96.22 \%$ & $54.59 \%$ & 1,925 & $\begin{array}{l}\text { Bike Route with Striped } \\
\text { Shoulder }\end{array}$ \\
\hline 3 & 22 & 4,500 & $1.11 \%$ & $0.00 \%$ & 50 & $<$ Null> \\
\hline 4 & 335 & 3,475 & $100.00 \%$ & $\begin{array}{r}100.00 \\
\%\end{array}$ & 0 & $\begin{array}{l}\text { Bike Route with Striped } \\
\text { Shoulder }\end{array}$ \\
\hline 5 & 51 & 4,575 & $100.00 \%$ & $8.20 \%$ & 4,200 & Shared Lane Markings \\
\hline 6 & 19 & 4,375 & $97.71 \%$ & $15.43 \%$ & 3,600 & $\begin{array}{l}\text { Bike Route with Striped } \\
\text { Shoulder }\end{array}$ \\
\hline 7 & 215 & 4,425 & $100.00 \%$ & $19.21 \%$ & 3,575 & $\begin{array}{l}\text { Bike Route with Striped } \\
\text { Shoulder }\end{array}$ \\
\hline 9 & 39 & 4,575 & $1.09 \%$ & $0.00 \%$ & 50 & Shared Lane Markings \\
\hline 10 & 124 & 2,225 & $14.61 \%$ & $14.61 \%$ & 0 & Residential Streets \\
\hline & 143 & 3,550 & $47.89 \%$ & $47.89 \%$ & & $\begin{array}{l}\text { Bike Route with Striped } \\
\text { Shoulder }\end{array}$ \\
\hline
\end{tabular}

Table 3.9 Comparison among priority segments to the west before and after $\mathrm{Gl}$ implementation

\begin{tabular}{r|r|r|r|r|r|l}
\hline \multicolumn{1}{l|}{$\begin{array}{l}\text { Priority } \\
\text { Site \# }\end{array}$} & $\begin{array}{l}\text { Bike Flow } \\
\text { to West } \\
\text { (Count/ } \\
\text { Day) }\end{array}$ & $\begin{array}{l}\text { Area } \\
\text { of Bike } \\
\text { Lane } \\
\text { (SQFT) }\end{array}$ & $\begin{array}{l}\text { \%Area > } \\
\text { 3" (Pre) }\end{array}$ & $\begin{array}{l}\text { \%Area > } \\
\text { 3" (Post) }\end{array}$ & $\begin{array}{l}\text { Mitigated } \\
\text { Area } \\
\text { (SQFT) }\end{array}$ & BikeRouteType \\
\hline 1 & 244 & 3,475 & $91.37 \%$ & $46.76 \%$ & 1,550 & $\begin{array}{l}\text { Bike Blvd/Shared Lane } \\
\text { Markings }\end{array}$ \\
\hline 2 & 345 & 12,375 & $72.12 \%$ & $69.70 \%$ & 300 & $\begin{array}{l}\text { Bike Route with Striped } \\
\text { Shoulder }\end{array}$ \\
\hline 3 & 282 & 4,425 & $1.13 \%$ & $2.26 \%$ & -50 & $\begin{array}{l}\text { Bike Blvd/Shared Lane } \\
\text { Markings }\end{array}$ \\
\hline 4 & 18 & 4,050 & $29.01 \%$ & $11.73 \%$ & 700 & $\begin{array}{l}\text { Bike Route with Striped } \\
\text { Shoulder }\end{array}$ \\
\hline 6 & 224 & 2,175 & $100.00 \%$ & $35.63 \%$ & 1,400 & $\begin{array}{l}\text { Bike Blvd/Shared Lane } \\
\text { Markings }\end{array}$ \\
\hline 7 & 258 & 3,825 & $19.61 \%$ & $15.03 \%$ & 175 & $\begin{array}{l}\text { Bike Blvd/Shared Lane } \\
\text { Markings }\end{array}$ \\
\hline 8 & 14 & 4,125 & $33.94 \%$ & $1.21 \%$ & 1,350 & $<$ Null> \\
\hline 9 & 163 & 2,075 & $2.41 \%$ & $0.00 \%$ & 50 & $\begin{array}{l}\text { Bike Blvd/Shared Lane } \\
\text { Markings }\end{array}$ \\
\hline 10 & 67 & 3,175 & $100.00 \%$ & $100.00 \%$ & $\begin{array}{l}\text { Bike Route with Striped } \\
\text { Shoulder }\end{array}$ \\
\hline
\end{tabular}

Table 3.10 Comparison between all the priority sites before and after GI implementation 


\begin{tabular}{|c|c|c|c|c|}
\hline $\begin{array}{l}\text { Priority } \\
\text { Site \# }\end{array}$ & $\begin{array}{l}\text { Total Area of All } \\
\text { Road (SQFT) }\end{array}$ & $\begin{array}{l}\text { \%Area > 3" } \\
\text { (Pre) }\end{array}$ & $\begin{array}{l}\text { \%Area > 3" } \\
\text { (Post) }\end{array}$ & $\begin{array}{l}\text { Mitigated Area } \\
\text { (SQFT) }\end{array}$ \\
\hline 1 & 954,175 & $45.16 \%$ & $36.72 \%$ & 80,600 \\
\hline 2 & $1,670,125$ & $40.38 \%$ & $22.40 \%$ & 300,275 \\
\hline 3 & $1,224,475$ & $44.56 \%$ & $29.27 \%$ & 187,225 \\
\hline 4 & $1,091,150$ & $35.05 \%$ & $20.78 \%$ & 155,675 \\
\hline 5 & $1,342,950$ & $39.81 \%$ & $16.80 \%$ & 308,950 \\
\hline 6 & 340,625 & $36.75 \%$ & $16.26 \%$ & 69,800 \\
\hline 7 & $1,782,325$ & $43.65 \%$ & $24.97 \%$ & 333,025 \\
\hline 8 & $1,658,250$ & $37.96 \%$ & $14.33 \%$ & 391,850 \\
\hline 9 & 382,975 & $35.13 \%$ & $31.46 \%$ & 14,025 \\
\hline 10 & $1,222,775$ & $35.05 \%$ & $23.47 \%$ & 141,525 \\
\hline
\end{tabular}

\subsection{PEDESTRIAN ACCESS TO BUS STOPS: TEN PEDESTRIAN PRIORITY SITES AND SEGMENTS}

Pedestrian bus stop access included a 70 by 20 foot box around the bus stop and a pedestrian path on each side of the street throughout the priority site street network. Intersections are included in the pedestrian network by connecting the outer points of sidewalks and including the whole intersection. Figure 2.5 presents an example of how pedestrian network sites and segments with access to bus stops were analyzed. GI was implemented in the first five feet of the right-of-way while the next five feet were reserved for pedestrian access (see Figure 2.5 section). Water depths at or over three inches ( 0.25 feet) were considered inaccessible; water depths under three inches $(0.25$ feet) were considered accessible. Tables 3.11-3.16 report results of the ten pedestrian priority sites and segments.

Table 3.11 Comparison between all the priority sites before and after $\mathrm{Gl}$ implementation

\begin{tabular}{r|r|r|r}
$\begin{array}{l}\text { Priority } \\
\text { Site \# }\end{array}$ & $\begin{array}{l}\text { Total Area of Delineated } \\
\text { Sub-basin (SQFT) }\end{array}$ & \%Area of GI & \%lmpervious \\
\hline 1 & $10,418,150$ & $13.02 \%$ & $69.98 \%$ \\
\hline 2 & $15,824,425$ & $9.38 \%$ & $54.07 \%$ \\
\hline 3 & $11,189,350$ & $13.02 \%$ & $64.07 \%$ \\
\hline 4 & $13,788,000$ & $9.97 \%$ & $51.60 \%$ \\
\hline 5 & $12,939,975$ & $10.39 \%$ & $52.42 \%$ \\
\hline 6 & $11,413,800$ & $15.26 \%$ & $65.35 \%$ \\
\hline 7 & $25,185,625$ & $10.27 \%$ & $52.46 \%$ \\
\hline 8 & $12,758,525$ & $12.66 \%$ & $71.03 \%$ \\
\hline 9 & $25,002,475$ & $10.52 \%$ & $65.14 \%$ \\
\hline 10 & $2,556,850$ & $13.22 \%$ & $64.37 \%$ \\
\hline
\end{tabular}


Table 3.12 Results from pedestrian access to bus stops

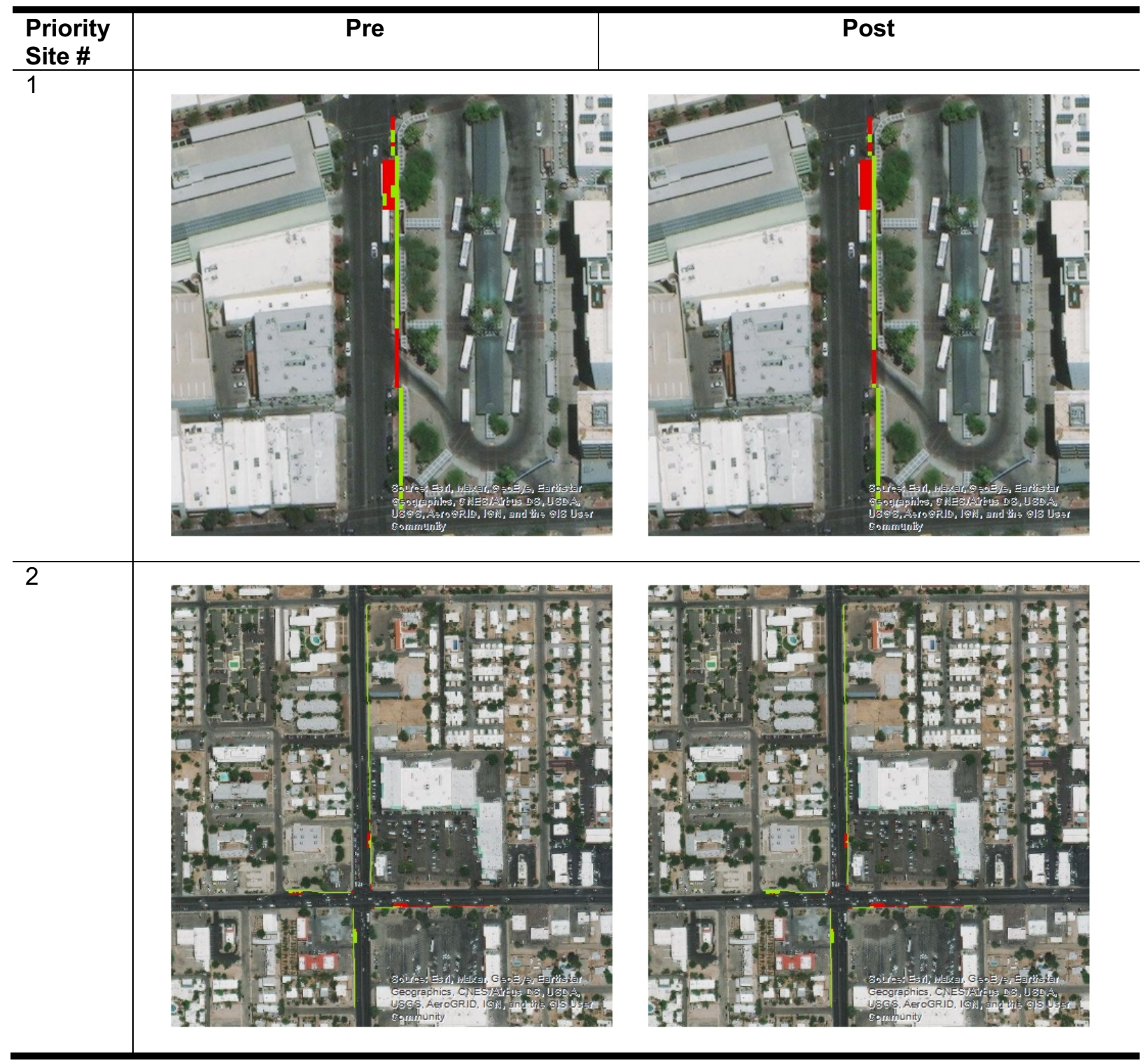




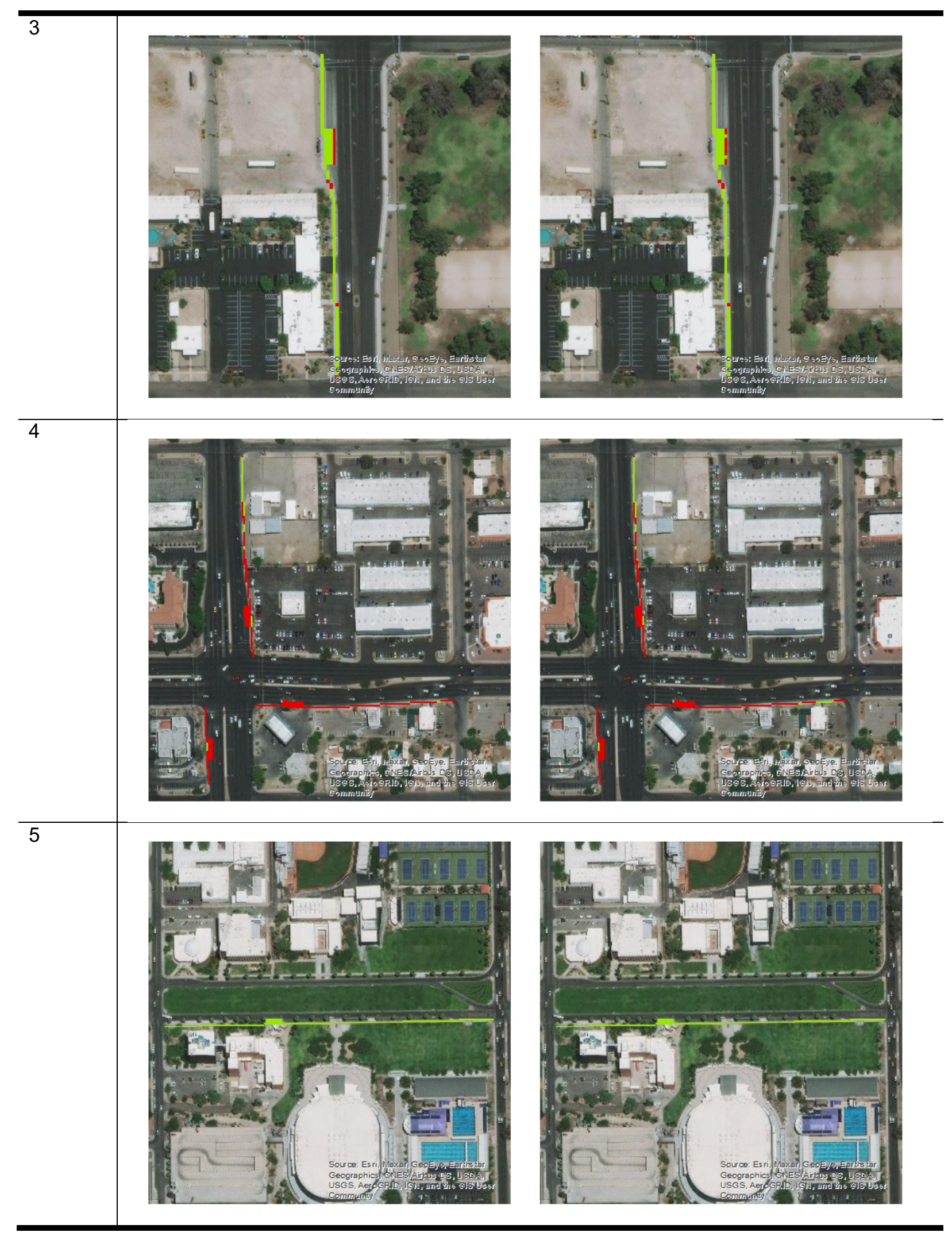




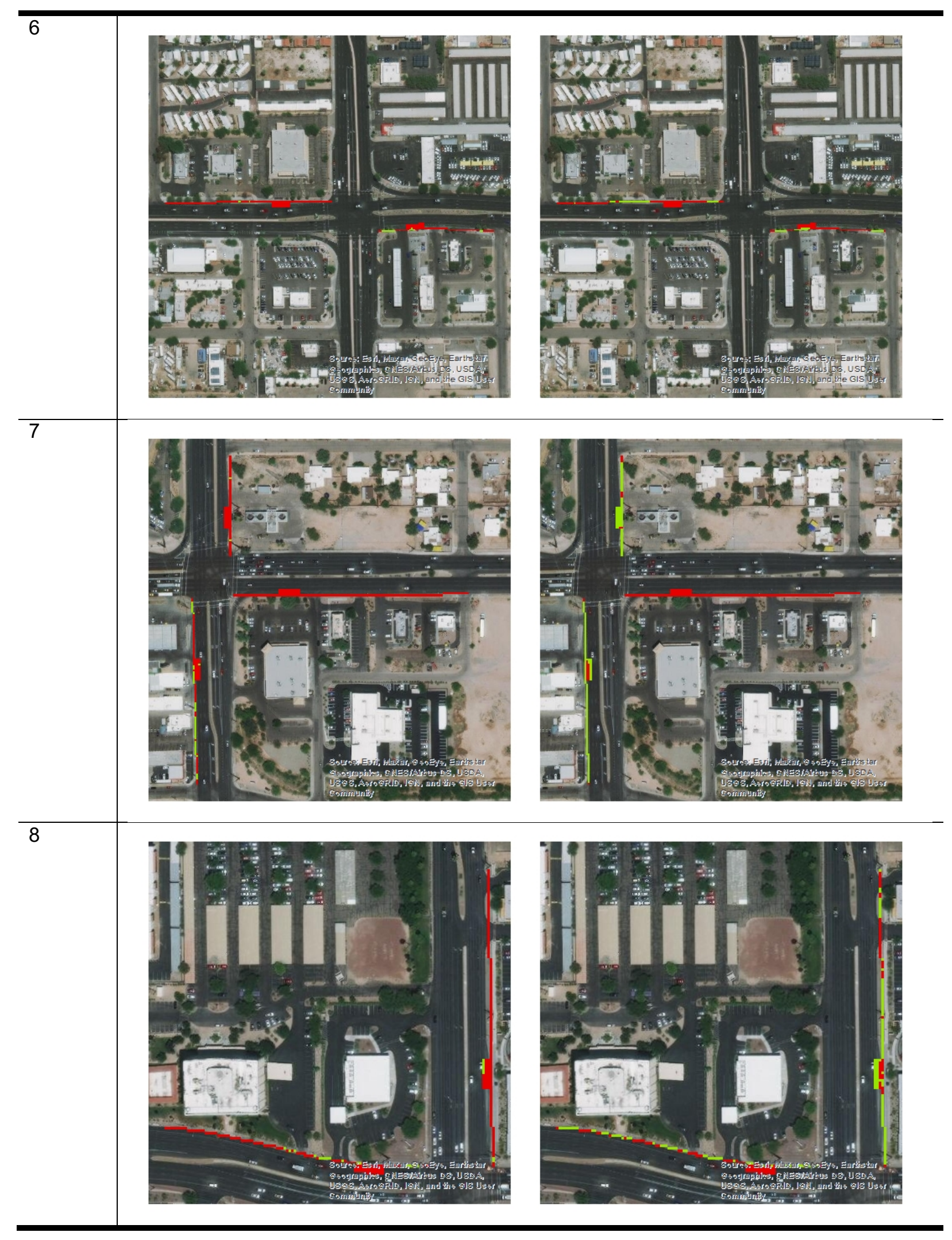




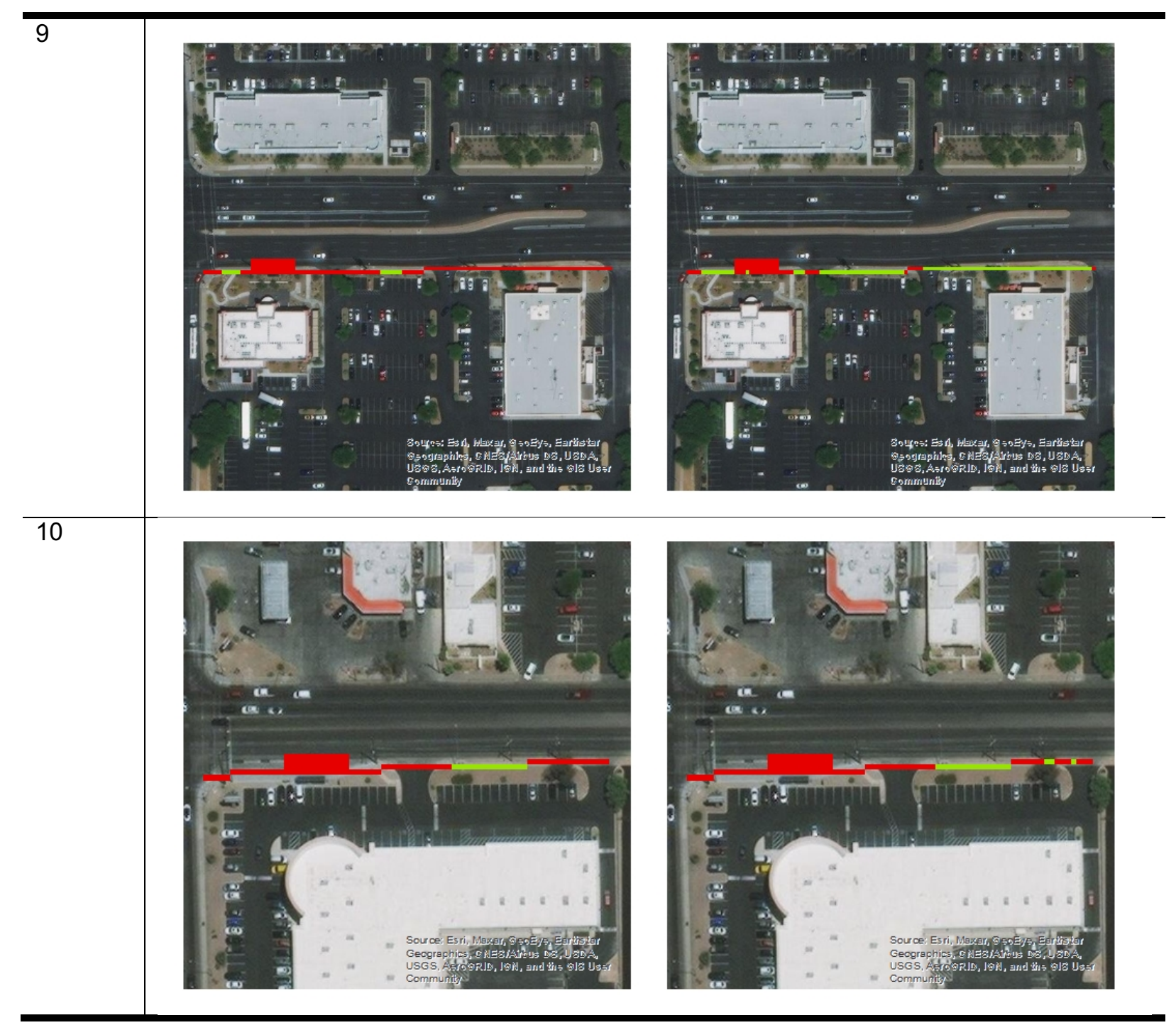

Table 3.13 Comparison between all the priority segments before and after $\mathrm{GI}$

\begin{tabular}{r|r|r|r|r|r|r}
\hline $\begin{array}{l}\text { Priority } \\
\text { Site \# }\end{array}$ & \multicolumn{1}{|l|}{$\begin{array}{l}\text { Stop Id } \\
\text { (Count/ } \\
\text { Day) }\end{array}$} & $\begin{array}{l}\text { Evaluated } \\
\text { Area } \\
\text { (SQFT) }\end{array}$ & $\begin{array}{l}\text { \%Area > } \\
\text { 3" (Pre) }\end{array}$ & $\begin{array}{l}\text { \%Area } \\
\text { > 3" } \\
\text { (Post) }\end{array}$ & $\begin{array}{l}\text { Mitigated } \\
\text { Area (SQFT) }\end{array}$ \\
\hline 1 & 42 & 2128 & 3250 & $37.69 \%$ & $39.23 \%$ & -50 \\
\hline 2 & 107 & 1145 & 7200 & $13.19 \%$ & $13.54 \%$ & -25 \\
\hline & 121 & 955 & 3075 & $1.63 \%$ & $1.63 \%$ & 0 \\
\hline & 124 & 733 & 2425 & $22.68 \%$ & $8.25 \%$ & 350 \\
\hline 3 & 15679 & 733 & 3700 & $70.27 \%$ & $69.59 \%$ & 25 \\
\hline 4 & 41167 & 696 & 3675 & $12.24 \%$ & $10.20 \%$ & 75 \\
\hline & 11610 & 646 & 3750 & $98.67 \%$ & $92.00 \%$ & 250 \\
\hline & 10981 & 598 & 2000 & $93.75 \%$ & $93.75 \%$ & 0 \\
\hline
\end{tabular}




\begin{tabular}{r|r|r|r|r|r|r}
\hline 5 & 100 & 645 & 7000 & $0.00 \%$ & $0.00 \%$ & 0 \\
\hline 6 & 184 & 585 & 3600 & $97.92 \%$ & $77.08 \%$ & 750 \\
\hline & 187 & 551 & 2800 & $85.71 \%$ & $72.32 \%$ & 375 \\
\hline 7 & 136 & 572 & 3475 & $66.91 \%$ & $16.55 \%$ & 1750 \\
\hline & 139 & 553 & 2275 & $97.80 \%$ & $9.89 \%$ & 2000 \\
\hline & 71 & 364 & 4150 & $100.00 \%$ & $100.00 \%$ & 0 \\
\hline 8 & 81 & 492 & 3875 & $94.84 \%$ & $34.19 \%$ & 2350 \\
\hline & 86 & 391 & 3550 & $86.62 \%$ & $55.63 \%$ & 1100 \\
\hline 9 & 13501 & 418 & 3675 & $92.52 \%$ & $44.22 \%$ & 1775 \\
\hline 10 & 342 & 413 & 2800 & $87.50 \%$ & $84.82 \%$ & 75 \\
\hline
\end{tabular}

Table 3.14 Comparison between all the priority sites before and after $\mathrm{GI}$

\begin{tabular}{|c|c|c|c|c|}
\hline $\begin{array}{l}\text { Priority } \\
\text { Site \# }\end{array}$ & $\begin{array}{l}\text { Total Area of } \\
\text { All Road } \\
\text { (SQFT) }\end{array}$ & $\begin{array}{l}\% \text { Area > } \\
\text { 3" } \\
\text { (Existing) }\end{array}$ & $\begin{array}{l}\text { \%Area > } \\
\text { 3" (GI) }\end{array}$ & $\begin{array}{l}\text { Mitigated } \\
\text { Area (SQFT) }\end{array}$ \\
\hline 1 & 686000 & $35.59 \%$ & $21.33 \%$ & 97850 \\
\hline 2 & 980050 & $36.09 \%$ & $29.53 \%$ & 64275 \\
\hline 3 & 1033225 & $41.43 \%$ & $28.74 \%$ & 131125 \\
\hline 4 & 962975 & $29.57 \%$ & $23.07 \%$ & 62625 \\
\hline 5 & 881300 & $31.24 \%$ & $25.45 \%$ & 51000 \\
\hline 6 & 812875 & $31.37 \%$ & $22.72 \%$ & 70350 \\
\hline 7 & 1307550 & $34.15 \%$ & $25.09 \%$ & 118425 \\
\hline 8 & 816150 & $29.20 \%$ & $20.00 \%$ & 75150 \\
\hline 9 & 1481750 & $31.19 \%$ & $21.11 \%$ & 149450 \\
\hline 10 & 145525 & $41.64 \%$ & $25.53 \%$ & 23450 \\
\hline
\end{tabular}

\subsection{LIMITATIONS}

There are several limitations to this modelling work of transportation and hydrological conditions that have been noted during the processing of results. The Stage 1 results (at 20 foot resolution) used as a baseline assessment for the entire City had results that varied from the Stage 3 model results (at the finer 5 foot resolution). In order to systematically model the hydrology of the whole city to identify the priority locations, this 20 foot grid was a computation limitation of the Flo-2D hydrological model.

Additionally, some Gl implementations in heavily flooded areas had a spill-over effect to surrounding areas. Although the County mandated nine inch $\mathrm{Gl}$ depth maximum was followed and GI implementations were successful at concentrating the flood water to an area outside of the road condition, with our coarse implementation strategy, there was sometimes an increase in flooding to Gl-adjacent areas. Traffic scenario \#1 and pedestrian scenario \#8 are examples of this spill-over effect. 


\subsection{PRELIMINARY CONCLUSIONS}

This section provides preliminary conclusions based on initial observations during the processing of the results and highlights areas for future work. Five key design principles and effects such as time duration and co-benefits are discussed. Presentations via zoom are scheduled this summer with staff from Pima County Regional Flood Control District, Tucson Department of Transportation and Mobility, and Tucson Water to obtain further feedback on implication, limitations, and future directions of the study. This summer, in addition to external presentations of the work to the City and County, an academic publication of the results is being written.

\subsection{MAXIMIZING GI INVESTMENT TO IMPROVE MULTIMODAL MOBILITY AND ACCESSIBILITY: 5 KEY DESIGN PRINCIPLES}

This section outlines five key principles to improve GI design performance that emerged during the Stage 4 Impact Assessment. These five principles can be used by transportation planners and engineers, hydrologists, flood managers, and urban designers when approaching and evaluating GI project sites and investments to maximize the impact on increased multimodal accessibility. The five principles are: (1) prioritize upstream mitigation, (2) prioritize moderate flooding areas, (3) prioritize network gains, (4) prioritize sites with large right-of-way areas, and (5) prioritize locations with high pedestrian travel demands.

\subsubsection{Principle 1: Prioritize Upstream Mitigation}

Across the thirty scenarios, the priority segments with the greatest improved transportation access were in areas that had substantial upstream mitigation. This result suggests that GI should not only be implemented directly adjacent to priority transit locations, but also (and sometimes more importantly) implemented upstream of the priority segment. Although citizen flood complaints and maintenance concerns may center directly where flood waters accumulate most acutely, it is important to examine upstream opportunities for $\mathrm{Gl}$ that can in aggregate address the specific area of concern and concerns throughout the watershed. GI depends on the accrual of many small scale implementations to have a lasting impact (as compared to a large multi-foot deep basin that is a single, large scale feature).

\subsubsection{Principle 2: Prioritize Moderate Flooding}

Across the thirty scenarios, the greatest impact on improved transportation access were in areas that received moderate flooding, in comparison to areas of extreme flooding. Overall, none of the 30 priority segments were completely mitigated from flooding. For cars, several locations do become passable across several lanes of travel. These locations experienced more moderate flooding. Similarly, no bicycle access path was completely mitigated of flooding. There did not appear to be a significant difference between shared road conditions and bicycle lane cases. Again, GI implementation had 
the largest impact when applied in moderate flooding conditions. The same results were seen for pedestrian access to bus stops.

Often municipalities and transportation agencies are motivated to place $\mathrm{Gl}$ installations in rights-of-way adjacent to areas where there are the greatest flooding concerns and highest volume of citizen complaints. Our research suggests that volume of citizen complaint or depth of flooding may not be the best criterion to identify $\mathrm{Gl}$ implementation locations for maximum impact. Rather, areas of moderate flooding with accessibility concerns showed the greatest impact from comprehensive GI implementations at a neighborhood-scale. To address areas of extreme flooding, larger implementations (such as underground stormwater piping or large basins) would need to be implemented in concert with the $\mathrm{GI}$ investments. Thus, for the $\mathrm{GI}$ installation to visibly show an impact on reducing flooding and increasing accessibility to the multimodal network, moderate flooded sites are the best candidates unless the municipality has additional funding to implement larger scale flood control measures. Future research will clarify these exact investment trade-offs and evaluate flood magnitude and GI effectiveness. This Small Starts grant successfully provided the research team with an initial understanding of the issues at play, so that future research can pinpoint the exact dynamics.

\subsubsection{Principle 3: Prioritize Network Gains}

When selecting project sites for $\mathrm{Gl}$ implementation, it is critical to consider the network gains that can be accomplished by concentrating the Gl implementation within an area. By addressing the flooding issue in one street or sidewalk segment, other downstream flooding concerns may be helped as well. When evaluating and designing GI projects, the larger hydrological and transportation networks connected to that project area should be considered as part of the potential design strategy and outcomes.

\subsubsection{Principle 4: Prioritize Large Right-of-Way Areas}

Across the thirty sites and segments, the largest impacts often occurred when there was a substantial amount of right-of-way available for implementation. When selecting and prioritizing projects for GI implementation, the area (and corresponding volume) of the available right-of-way for implementation is critical to long term performance and impact. Taken into consideration with the other four principles outlined, the availability of rightof-way can make a large impact on total flood reduction success.

\subsubsection{Principle 5: Prioritize Pedestrian Travel Locations}

The greatest impacts of GI on accessibility were in the pedestrian access to bus stop cases. The width of these designated areas to mitigate were smaller in the pedestrian cases compared to bicycle and vehicle cases. Acting as a buffer between road and pedestrian walking areas, the GI implementations most successfully supported greater access. However, consistent with the other two modes, Gl did little to mitigate impact in high volume flooding cases. Further work is needed to complete the full analysis of the results and development of conclusions. 


\subsection{OPTIMIZING CO-BENEFITS}

The co-benefits of GI are an important considerations in GI site selection for a transportation network. For example, shading from trees in Gl installations can transform an exposed walking or bicycle path into one that is more accessible during times of day for vulnerable populations that may have issues in extreme heat. As the majority of sites were mitigated but still did not meet base accessibility thresholds, cooptimizing site selection with other factors could provide useful additional criteria for site selection, particularly in the case of pedestrian access. As this Small Starts grant aimed to consider equity, it is important to note that these co-benefits are neighborhood-scale and focused on modes of transportation more widely used by lower socio-economic statuses.

\subsection{MODELLING TIME DURATION}

Time duration of flooding events is a critical dynamic. This Small Starts grant, as a preliminary study, evaluated accessibility with peak flooding criteria at a single time. Despite many sites not meeting accessibility thresholds after $\mathrm{Gl}$ implementation, it is possible with more nuanced modelling of flood reduction over time some sites/segments would become fully accessible within short time durations. This pre and post-peak flood reduction would make a large impact on mobility despite the single peak outcome observed in this preliminary study. Future research will investigate how long these peak events occur and how quickly $\mathrm{Gl}$ installations facilitate a return to accessibility of the multimodal transportation network.

\subsection{FUTURE WORK}

The research team will disseminate this research in several venues this summer and into next year. First, summer presentations via zoom are scheduled with staff from Pima County Regional Flood Control District, Tucson Department of Transportation and Mobility, and Tucson Water to obtain further feedback. An academic article is currently being written to disseminate this work and results to a broader audience. Additionally, the team plans to submit to the Transportation Research Board conference to communicate with an audience of academics and practitioners. The research team has secured additional future cost-share commitments from Tucson Department of Transportation and Mobility and Pima County Regional Flood Control District to apply for new funding to continue this work. The team is currently completing a submission for a NITC General Grant to fund further analysis and the creation of a decision support tool for the City and County to optimize across a Complete 'Green' Streets framework. The team also aims to apply to other grant opportunities through the National Science Foundation. 


\section{CITATIONS}

Ault, Toby R., et al. "Relative impacts of mitigation, temperature, and precipitation on 21st-century megadrought risk in the American Southwest." Science Advances 2.10 (2016): e1600873.

Bakkensen, Laura and Riana Johnson. "The Economic Impacts of Extreme Weather: Tucson and Southern Arizona's Current Risks and Future Opportunities." Making Action Possible for Southern Arizona, 2017.

Environmental Protection Agency. "What is Green Infrastructure?" EPA: Washington DC (2020).

Jaffe, Martin. "Environmental reviews \& case studies: reflections on Green Infrastructure economics." Environmental Practice 12, no. 4 (2010): 357-365.

Pima County Regional Flood Control District, City of Tucson (2015). Low Impact Development and Green Infrastructure Guidance Manual.

National Research Council. Potential impacts of climate change on US transportation: Special report 290. Vol. 290. Transportation Research Board, 2008.

Tzoulas, Konstantinos, Kalevi Korpela, Stephen Venn, Vesa Yli-Pelkonen, Aleksandra Kaźmierczak, Jari Niemela, and Philip James. "Promoting ecosystem and human health in urban areas using Green Infrastructure: A literature review." Landscape and urban planning 81, no. 3 (2007): 167-178.

United States Census Bureau. "American community survey." (2016).

Wuebbles, Donald J., David W. Fahey, and Kathy A. Hibbard. "Climate science special report: fourth national climate assessment, volume I." (2017). 


\section{APPENDIX A}

\section{A-1 ROUGHNESS}

\begin{tabular}{l|c}
\hline Land Cover & Manning's n \\
\hline Water & 0.01 \\
\hline Roads & 0.02 \\
\hline Structures & 0.024 \\
\hline Desert/Grassland/Scrub & 0.04 \\
\hline Tree/Shrubs & 0.055 \\
\hline Irrigated Land & 0.06 \\
\hline Impervious & 0.026 \\
\hline Barren/Bedrock & 0.065 \\
\hline
\end{tabular}

\section{A-2 INFILTRATION}

\begin{tabular}{l|c|c|c|c}
\hline & \multicolumn{5}{|c}{ Soil Group } \\
\hline Land Cover & A & B & C & D \\
\hline Water & 100 & 100 & 100 & 100 \\
\hline Trees/Shrubs & 83 & 83 & 88 & 91 \\
\hline Irrigated Land & 83 & 79 & 86 & 90 \\
\hline Desert/Grassland/Scrub & 81 & 83 & 86 & 89 \\
\hline Barren/Bedrock & 95 & 95 & 95 & 95 \\
\hline Impervious & 99 & 99 & 99 & 99 \\
\hline Structures & 99 & 99 & 99 & 99 \\
\hline Roads & 99 & 99 & 99 & 99 \\
\hline
\end{tabular}

